\title{
Signal perception and transduction in plant defense responses
}

\author{
Yinong Yang, Jyoti Shah, and Daniel F. Klessig ${ }^{1}$ \\ Waksman Institute and Department of Molecular Biology and Biochemistry, Rutgers, The State University of New Jersey, \\ Piscataway, New Jersey 08855 USA
}

Plant diseases have major effects on agricultural production and the food supply. Currently, worldwide crop losses due to disease are estimated to exceed $\$ 100$ billion (Brears and Ryals 1994). Although application of fungicides and pestcides has helped control plant diseases, chemical control is economically costly as well as environmentally undesirable. Therefore, the development of new strategies based on a plant's own defense mechanisms for disease control is critical for sustaining agricultural production and improving our environment and health.

Plant disease resistance and susceptibility are governed by the combined genotypes of host and pathogen and depend on a complex exchange of signals and responses occurring under given environmental conditions. During the long process of host-pathogen coevolution, plants have developed various elaborate mechanisms to ward off pathogen attack. Whereas some of these defense mechanisms are preformed and provide physical and chemical barriers to hinder pathogen infection, others are induced only after pathogen attack. Similar to animal immune responses, induced plant defense responses involve a network of signal transduction and the rapid activation of gene expression following pathogen infection. Recent studies have revealed intriguing parallels between animal and plant defense responses as demonstrated by the structural and functional conservation of some of their signal transduction processes. For example, several plant disease resistance $(R)$ genes, which confer recognition and resistance to specific plant pathogens, were shown to encode an amino-terminal domain homologous to the cytoplasmic signaling domain of the mammalian interleukin-1 receptor and Drosophila Toll protein (Whitham et al. 1994; Lawrence et al. 1995; Anderson et al. 1997). The interleukin-1 receptor and Toll mediate cytokine-induced activation of NF-кB or Spätzle-induced activation of Dif/Dorsal, respectively, thereby leading to antimicrobial defense responses. In Drosophila, the genes spätzle, Toll, tube, pelle, and cactus are all re-

ICorresponding author.

E-MAIL klessig@mbcl.rutgers.edu; FAX (908) 445-5735. quired for the activation of a defense response that involves, in part, the induction of an antifungal peptide called drosomycin (Lemaitre et al. 1996). Interestingly, plant proteins that share homology with Pelle (e.g., tomato Pto), Cactus (e.g., Arabidopsis NPR1/NIM1), and drosomycin (e.g., the radish defensin Rs-AFP1) are also important for disease resistance (Martin et al. 1993; Fehlbaum et al. 1994; Terras et al. 1995; Cao et al. 1997; Ryals et al. 1997). Furthermore, signaling components such as $\mathrm{G}$ proteins, NADPH oxidase, $\mathrm{H}_{2} \mathrm{O}_{2}$, salicylic acid (SA, and aspirin), mitogen-activated protein kinases (MAPK), and Myb transcription factors have been shown to be associated with or participate in both animal and plant defense responses, suggesting the presence of conserved signaling pathways for host defenses in diverse higher eukaryotes.

A key difference between resistant and susceptible plants is the timely recognition of the invading pathogen and the rapid and effective activation of host defense mechanisms. A resistant plant is capable of rapidly deploying a wide variety of defense responses that prevent pathogen colonization. In contrast, a susceptible plant exhibits much weaker and slower responses that fail to restrict pathogen growth and/or spread. As a result, a susceptible plant is often severely damaged or even killed by pathogen infection. The activation of defense responses in plants is initiated by host recognition of pathogen-encoded molecules called elicitors (e.g., microbial proteins, small peptides, and oligosaccharides, etc). The interaction of pathogen elicitors with host receptors (many of which may be encoded by $R$ genes) likely activates a signal transduction cascade that may involve protein phosphorylation, ion fluxes, reactive oxygen species (ROS), and other signaling events (see Fig. 3, below). Subsequent transcriptional and/or post-translational activation of transcription factors eventually leads to the induction of plant defense genes (Zhu et al. 1996). In addition to eliciting primary defense responses, pathogen signals may be amplified through the generation of secondary plant signal molecules such as SA (Durner et al. 1997). Both primary pathogen elicitors and secondary endogenous signals may activate a diverse array of plant protectant and defense genes, whose products include glutathione 
$S$-transferases (GST), peroxidases, cell wall proteins, proteinase inhibitors, hydrolytic enzymes (e.g., chitinases and $\beta-1,3$-glucanases), pathogenesis-related (PR) proteins, and phytoalexin biosynthetic enzymes, such as phenylalanine ammonia lyase (PAL) and chalcone synthase (CHS, Hammond-Kosack and Jones 1996). The PR proteins are host-encoded, abundant proteins induced by pathogens and many of them have antimicrobial activity in vitro or when overexpressed in transgenic plants. Phytoalexins are low-molecular-weight, antimicrobial compounds (e.g., phenylpropanoids, terpenoids, etc), whose synthesis is induced following pathogen infection.

At the macroscopic level, induced defense responses are frequently manifested in part as a hypersensitive response (HR), which is characterized by necrotic lesions resulting from localized host cell death at the site of infection (Goodman and Novacky 1994; Fig. 1). Plant cell death occurring during the HR resembles animal programmed cell death (pcd) and may play a role in preventing the growth and spread of the pathogen into healthy tissues (Dangl et al. 1996; Greenberg 1996). In addition to the localized HR, many plants respond to pathogen infection by activating defense responses in uninfected parts of the plant. As a result, the entire plant becomes more resistant to subsequent infections. This systemic acquired resistance (SAR) is longlasting and often confers broad-based resistance to a variety of different pathogens (Ryals et al. 1996; Delaney 1997).

Over the last few years, significant progress has been made in understanding the signaling processes involved in plant-pathogen interactions. This review will focus on recent developments in the signal recognition, perception, and transduction mechanisms underlying induced plant defense responses.

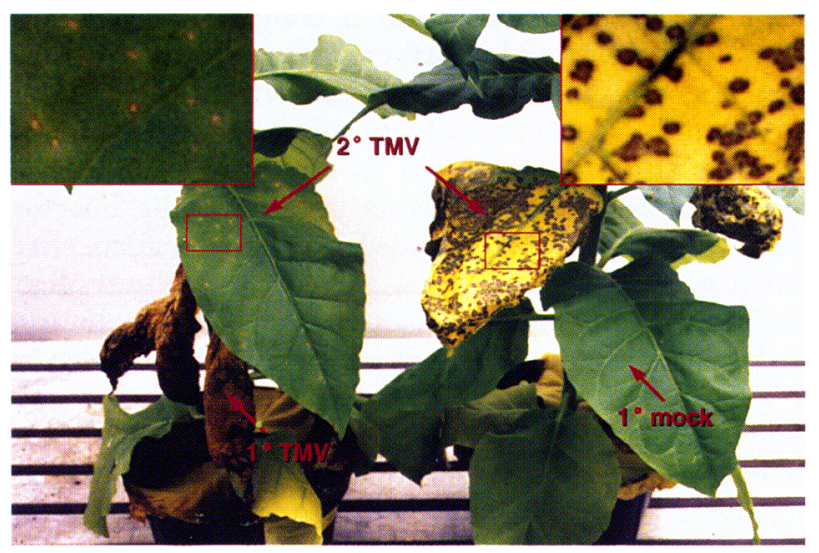

Figure 1. Hypersensitive response and systemic acquired resistance. TMV infection of tobacco plants that carry the $N$ resistance gene leads to the hypersensitive response (HR) and subsequent development of systemic acquired resistance (SAR) throughout the plant. In contrast to the mock-infected plant on the right, the plant on the left develops SAR after the primary infection, as shown by the decreased lesion size and number (see insets) produced after the secondary infection of upper leaves.

\section{Host recognition of pathogen elicitors}

\section{The gene-for-gene specificity}

When a plant is infected by a pathogen, the plant must recognize the pathogen and then initiate defense responses to limit the potential damage that can be caused by the pathogen. Host recognition of the invading pathogen often is determined by the so-called "gene-for-gene" interaction between a dominant avirulence $(a v r)$ gene in the pathogen and a corresponding dominant $R$ gene in the host (Flor 1971). For example, the $C f 9$ resistance gene in tomato mediates specific resistance only towards the races of the fungal pathogen Cladosporium fulvum that carries the avr 9 gene. Therefore, activation of defense responses requires the expression of a matching pair of plant $R$ genes and pathogen avr genes.

The primary biological function of avr genes is believed not to trigger plant defense responses, which could negatively affect pathogen's own survival. Rather, recent studies have shown that some avr genes may be important for pathogen fitness and/or pathogenicity (Kearny and Staskawicz 1990; Dangl 1994; Yang et al. 1996). Many avr genes have likely originated from virulence genes that contribute to the ability of the pathogen to grow on the host, but which have been subsequently recognized by evolving $R$ genes in resistant host plants. Dozens of avr genes have been isolated and characterized from bacterial and fungal pathogens. However, biochemical function of their products remains unknown (Leach and White 1996). One exception is the avrD gene of Pseudomonas syringae pathovar (pv.) tomato, which appears to encode an enzyme involved in the production of glycolipid elicitors (Midland et al. 1993).

\section{Plant R genes}

It has long been postulated that plant $R$ genes encode receptors for the recognition of specific elicitors or ligands encoded directly or indirectly by pathogen $a v r$ genes (Gabriel and Rolfe 1990). During the past five years, at least a dozen $R$ genes have been isolated by map-based cloning or transposon tagging from various plant species (Bent 1996; Jones 1996; Baker et al. 1997). Although these $R$ genes confer specific resistance to different viral, bacterial, fungal, or nematode pathogens, interestingly, most of them encode one or more common structural motifs. Except for Pto from tomato, all cloned $R$ genes that confer gene-for-gene specificities contain leucine-rich-repeats (LRRs). LRRs have been implicated in protein-protein interactions in animals (Kobe and Deisenhofer 1995) and may also be responsible for recognitional specificity in gene-for-gene interactions (Bent 1996; Jones 1996). Other common motifs include serine/ threonine kinase domains (e.g., Pto of tomato and $\mathrm{Xa} 21$ of rice; Martin et al. 1993; Song et al. 1995), nucleotide binding sites (e.g., RPS 2 and RPM1 of Arabidopsis, $N$ of tobacco, I2C of tomato, $L 6$ and $M$ of flax; Bent et al. 1994; Mindrinos et al. 1994; Whitham et al. 1994; Grant et al. 1995; Lawrence et al. 1995; Anderson et al. 1997; Ori et al. 1997), leucine zippers (e.g., RPS2 and RPM1 of Ara- 
bidopsis) and Toll/interleukin-1 receptor-like domains (e.g., $N$ of tobacco, $L 6$ and $M$ of flax). Such structural conservation within $R$ genes from a wide range of plant taxa suggests the presence of a common molecular mechanism underlying many gene-for-gene interactions. Based on sequence homologies within conserved motifs, several putative resistance genes have been isolated from soybean, potato, and wheat (Kanazin et al. 1996; Leister et al. 1996; Yu et al. 1996; Feuillet et al. 1997).

The predominance and diverse specificities of LRRcontaining $R$ genes may be explained partly by the presence of their internal repetitive sequences, which are potentially active sites for genomic recombination. Furthermore, plant $R$ genes are flanked frequently by multiple homologous alleles (Lawrence et al. 1995; Dixon et al. 1996; Jia et al. 1997). Therefore, the LRR-containing $R$ genes may undergo active intragenic and intergenic recombination that would contribute signficantly to the evolution of new specificities. Recent cloning and analayses of the flax $M$ gene, the tomato $I 2 C$ gene, and their mutant alleles suggest that genomic recombination within the LRR-encoding region may be important for the generation of structurally altered $R$ genes with, possibly, new resistance specificities (Anderson et al. 1997; Ori et al. 1997).

Interestingly, repetitive sequences are also found in some of the $a_{V r}$ genes from plant pathogens. Members of a Xanthomonas avirulence/pathogenicity (avr/pth) gene family, which consists of $>26$ genes and is the largest $a v r$ gene family known to date (Gabriel et al. 1996), encode nearly identical, leucine-rich, 34-amino-acid tandem repeats that determine avirulence and pathogenic specificities (Herbers et al. 1992; Yang et al. 1994). Both intragenic and intergenic recombination have been demonstrated to be involved in the rapid generation of new specificities in this avr gene family (De Feyter et al. 1993; Yang and Gabriel 1995b). Therefore, genomic recombination among homologous sequences appears to play an important role during the reciprocal evolution of gene-for-gene interactions.

\section{Interaction between $\mathrm{R}$ and avr gene products}

Based on sequence analyses, it has been predicted that some of the plant $R$ gene products are localized extracellularly (Fig. 2). For example, the tomato $C f 2$ and $C f 9$ genes confer resistance to specific races of the fungal pathogen $C$. fulvum and encode glycoproteins with putative extracellular LRRs, a transmembrane region, and a small cytoplasmic domain (Jones et al. 1994; Dixon et al. 1996). As Avr4 and Avr9 elicitors, which are small cysteine-rich proteins $(<15 \mathrm{kD})$, are secreted from $C$. fulvum into the intercellular fluid of infected plant tissues (De Wit 1995), they could interact readily with the extracellular LRR domains of Cf proteins. However, a direct interaction between Avr and Cf proteins has yet to be demonstrated. The rice $X a 21$ gene also encodes a protein with an extracellular LRR motif as well as an intracellular serine/threonine protein kinase domain (Song et al. 1995). Thus, it is possible that the AvrXa21 elicitor directly interacts with the Xa21 receptor-like kinase. Unfortunately, the identity of this Avr elicitor is unknown and the avrXa21 gene has yet to be isolated from the bacterial pathogen Xanthomonas oryzae.

Unlike Xa21 and Cf proteins, the products of other cloned plant $R$ genes do not contain transmembrane domains and appear to be localized intracellularly. An intracellular location poses no problem for $R$ gene products to interact with the elicitors of viral pathogens, which multiply inside plant cells. But how intracellular receptors interact with specific elicitors from extracellular pathogens was initially perplexing. Low-molecularweight elicitors like glycolipids may be taken into host plant cells and interact with intracellular receptors; however, no Avr protein has been found to be secreted by bacterial plant pathogens.

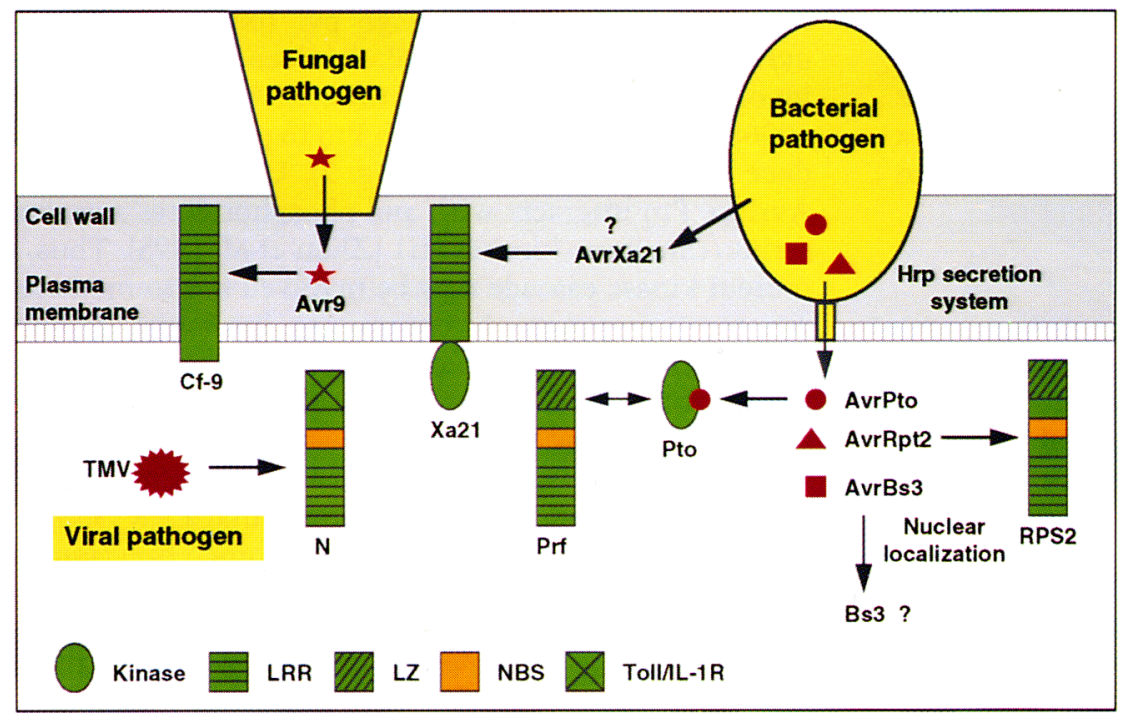

Figure 2. Molecular recognition in genefor-gene interactions. Race-specific elicitors encoded by fungal, bacterial, and viral avirulence genes are specifically recognized by extracellular or intracellular receptors encoded by corresponding plant resistance genes. As in the case of AvrPtoPto interaction, a direct interaction between $A v r$ and $R$ products likely determines the gene-for-gene specificity and initiates plant defense responses in many plant-pathogen interactions. Question marks indicate unknown elicitors or receptors. LRR, leucine-rich repeats; LZ, leucine zipper; NBS, nucleotide-binding site; Toll/IL$1 \mathrm{R}$, Toll- and interleukin-1 receptor-like domain 
The mechanism by which putative protein elicitors encoded by $a v r$ genes interact with intracellular $R$ gene products was elucidated by the discovery of the type III protein secretion pathway in bacterial pathogens. In animal pathogenic bacteria, such as Yersinia, Shigella, and Salmonella, the type III secretion pathway is used to transfer virulence proteins directly into animal host cells (Stephens and Shapiro 1996). The Hrp (hypersensitive response and pathogenicityl gene cluster found in phytopathogenic bacteria also encodes components of the type III secretion pathway. Expression of Hrp genes is required for bacterial avr gene products to elicit an HR on resistant plants carrying the corresponding $R$ genes and for pathogenicity of the pathogen on susceptible plants (Alfano and Collmer 1996). Some of the Hrp gene products appear to be involved in the formation of a pilus-like bridge between bacteria and plant cells (Roine et al. 1997), thereby providing an avenue for delivering Avr protein elicitors (or virulence factors) into host cells, where they can interact with intracellular receptors.

Recent studies have shown that several bacterial Avr proteins are indeed recognized inside host cells. Introduction of the $P$. syringae avrB or avrRpt2 gene into Arabidopsis by transient or stable transformation elicits an HR specifically in the plants carrying the corresponding RPM1 and RPS2 resistance genes (Gopalan et al. 1996; Leister et al. 1996). Scofield et al. (1996) and Tang et al. (1996) reported a similar effect when avrPto of $P$. syringae pv. tomato is expressed in tomato plants carrying the Pto resistance gene. Using the yeast two-hybrid system, they further demonstrated a direct physical interaction between AvrPto and Pto. Mutations in AvrPto or Pto that disrupted their interaction in yeast also abolished the resistance response in plants. Thus, the direct interaction of AvrPto with Pto determines the gene-forgene specificity and initiates plant defense responses. In addition to these Pseudomonas Avr proteins, AvrBs3 from Xanthomonas campestris pv. vesicatoria is also recognized inside plant cells following delivery via the $H r p$-encoded type III secretion system. The avrBs3 gene belongs to the family of Xanthomonas avr/pth genes that contain functional nuclear localization signals (Yang and Gabriel 1995a). Recently, AvrBs3 was shown to require its nuclear localization signals to elicit the resistance response, suggesting the involvement of a nuclear factor(s) in AvrBs3 perception (van den Ackerveken et al. 1996).

\section{Plant receptors for nonspecific elicitors}

In addition to specific resistance determined by the genefor-gene interaction, plant defense responses can be activated without a matching pair of $a v r$ and $R$ genes. Many fungal and bacterial oligosaccharides, proteins, and glycoproteins can function as nonspecific elicitors to induce defense responses in the plants carrying no specific $R$ genes (Benhamou 1996; Hahn 1996). Host recognition of general fungal elicitors is likely mediated by high affinity receptors present in plasma membranes. For instance, a 91-kD parsley plasma membrane protein has been identified as a receptor for the fungal protein elicitor from Phytophthora megasperma (Nürnberger et al. 1995). Recently, a 70-kD soybean $\beta$-glucan elicitor-binding protein has been purified from the membrane fraction of soybean root cells, and its cDNA isolated (Umemoto et al. 1997). Expression of the cDNA in tobacco suspension cultures and in Escherichia coli conferred $\beta$-glucan elicitor-binding activity. Furthermore, an antibody against the recombinant protein was shown to inhibit binding of $\beta$-glucan elicitors to soybean membranes and to block the induction of phytoalexins, suggesting that this protein functions as a receptor to mediate the action of the fungal elicitor.

\section{A central role for protein phosphorylation in intracellular signal transduction}

Protein kinases and phosphatases play a pivotal role in the signal transduction processes leading to cell growth, differentiation, and responses to environmental stimuli. Mounting evidence indicates that phosphorylation and dephosphorylation are also essential to early as well as later events along the signaling pathways leading to plant defense responses. Fungal elicitors trigger rapid and transient protein phosphorylation in parsley and tomato cell suspension cultures (Dietrich et al. 1990; Felix et al. 1991). Protein kinase inhibitors such as K-252a and staurosporine block these elicitor-induced changes in protein phosphorylation and prevent the induction of plant defense responses. In contrast, protein phosphatase inhibitors, such as calyculin A, cantharadin, and okadaic acid, mimic elicitor action to activate defense responses (Felix et al. 1994; Levine et al. 1994; Mackintosh et al. 1994).

The discovery that the tomato Pto and rice Xa21 resistance genes encode serine/threonine protein kinases further suggests a central role for protein phosphorylation in signal perception and transduction in disease resistance (Martin et al. 1993; Song et al. 1995). The intracellular Pto kinase requires an LRR-containing cytoplasmic protein, encoded by the closely linked Prf gene, for resistance against $P$. syrinage pv. tomato expressing avrPto (Salmeron et al. 1996). Prf does not appear to be involved in the specific recognition of AvrPto (Tang et al. 1996), but it may interact with Pto to perceive and transduce the avirulence signal (Fig. 2). Upon activation by AvrPto, Pto interacts with and phosphorylates a second serine/threonine kinase, Ptil (Zhou et al. 1995). Thus, a protein kinase cascade may be involved in Pto-mediated resistance responses. In contrast to Pto, most $R$ genes encode LRR motifs, but not a kinase domain. These $R$ genes may interact with a Pto-like kinase for signal transduction. The rice Xa21 resistance gene encodes a receptor-like kinase that contains an intracellular kinase domain as well as a putative extracellular LRR (Song et al. 1995); thus it may possess the combined functions of both Pto and Prf. In addition to Xa21, a few other receptor-like protein kinases have been implicated in plant disease resistance. The PR5K receptor-like kinase of Arabidopsis contains an extracellular domain homologous 
to the antimicrobial PR-5 protein, suggesting its possible involvement in the perception of pathogen signals (Wang et al. 1996). Recently, a receptor-like kinase (SFR2) belonging to the $S$ gene family, which mediates self-incompatibility in Brassica oleracea, was shown to be rapidly induced by wounding and bacterial infection (Pastuglia et al. 1997). Therefore, it may also play a role in signaling plant defense responses.

Protein phosphorylation/dephosphorylation is not only involved in early signal perception but also in downstream events leading to the activation of plant defense genes (Fig. 3). For example, elicitor-induced phosphorylation of the nuclear factor PBF-1 is required to increase its binding activity and thereby activate the potato PR-10a gene (Després et al. 1995). A functional homolog of mammalian protein kinase $C$ has recently been shown to be involved in this phosphorylation process (Subramamiam et al. 1997). Similarly, phosphorylation of $\mathrm{G} / \mathrm{HBF}-1$, a soybean bZIP transcription factor, by a bacterial pathogen-induced serine/threonine kinase enhances its binding activity to the chalcone synthase chs15 promoter (Dröge-Laser et al. 1997). Some of these transcription factors may be regulated by the MAPK cascade, which has been implicated in plant stress signal transduction (Jonak et al. 1996; Mizoguchi et al. 1996). Treatment of tobacco cells with fungal elicitors was shown to transiently activate a $47-\mathrm{kD}$ putative MAPK via tyrosine phosphorylation (Suzuki and Shinshi 1995). Activation of this $47-\mathrm{kD}$ kinase was inhibited by staurosporine and the $\mathrm{Ca}^{2+}$ channel blocker $\mathrm{Gd}^{2+}$ /gadolinium, a lanthanide), suggesting that upstream kinases and $\mathrm{Ca}^{2+}$ might be involved in the activation of this kinase. In addition, a wound-induced MAPK (WIPK) gene was isolated from tobacco (Seo et al. 1995). Transgenic plants with depressed WIPK activity exhibited increased SA levels and induction of the acidic $P R-1$ and $P R-2$ genes upon wounding. Because wounding wild-type tobacco does not induce SA production or $P R$ gene expression, these results suggest that protein phosphorylation mediates cross-talk between wound- and pathogen-induced signaling pathways.

Protein kinases and phosphatases are also involved in the development of HR, SAR, and the SA-mediated induction of $P R-1$ gene expression in tobacco plants. Okadaic acid was shown to inhibit the TMV-induced HR (Dunigan and Madlener 1995) and to block SA-induced PR-1 gene expression (Conrath et al. 1997). Phosphorylation of both a soluble and a plasma membrane-associated protein was induced during the development of SAR (Ye et al. 1995). Recent studies have demonstrated that SA induces a rapid and transient activation of a $48-\mathrm{kD}$ protein kinase in tobacco (Zhang and Klessig 1997). Based on sequences obtained from the purified kinase and its encoding cDNA, this SA-induced protein (SIP) kinase was shown to be a distinct member of a MAPK family. It will be interesting to see whether the SIP kinase phosphorylates any transcription factors involved in the induction of known defense genes.

\section{Ion fluxes, oxidative burst, and other early signaling events}

In addition to protein phosphorylation, early signaling events in plant defense responses may involve ion channels, ROS, GTP-binding proteins, phospholipases and/or other signaling components (Fig. 3). Various fungal and bacterial elicitors have been reported to trigger fluxes of $\mathrm{H}^{+}, \mathrm{K}^{+}, \mathrm{Cl}^{-}$, and $\mathrm{Ca}^{2+}$ across the plasma membrane (Atkinson et al. 1990, 1996; Mathieu et al. 1991; Bach et al. 1993; Kuchitsu et al. 1993; Popham et al. 1995). In parsley suspension cells, a transient influx of $\mathrm{Ca}^{2+}$ and $\mathrm{H}^{+}$ and an efflux of $\mathrm{K}^{+}$and $\mathrm{Cl}^{-}$are initiated within two to five minutes after the addition of a fungal oligopeptide elicitor (Hahlbrock et al. 1995). $\mathrm{Ca}^{2+}$ channel blockers were shown to inhibit ion fluxes as well as defense responses induced by fungal and bacterial elicitors (Nürn-

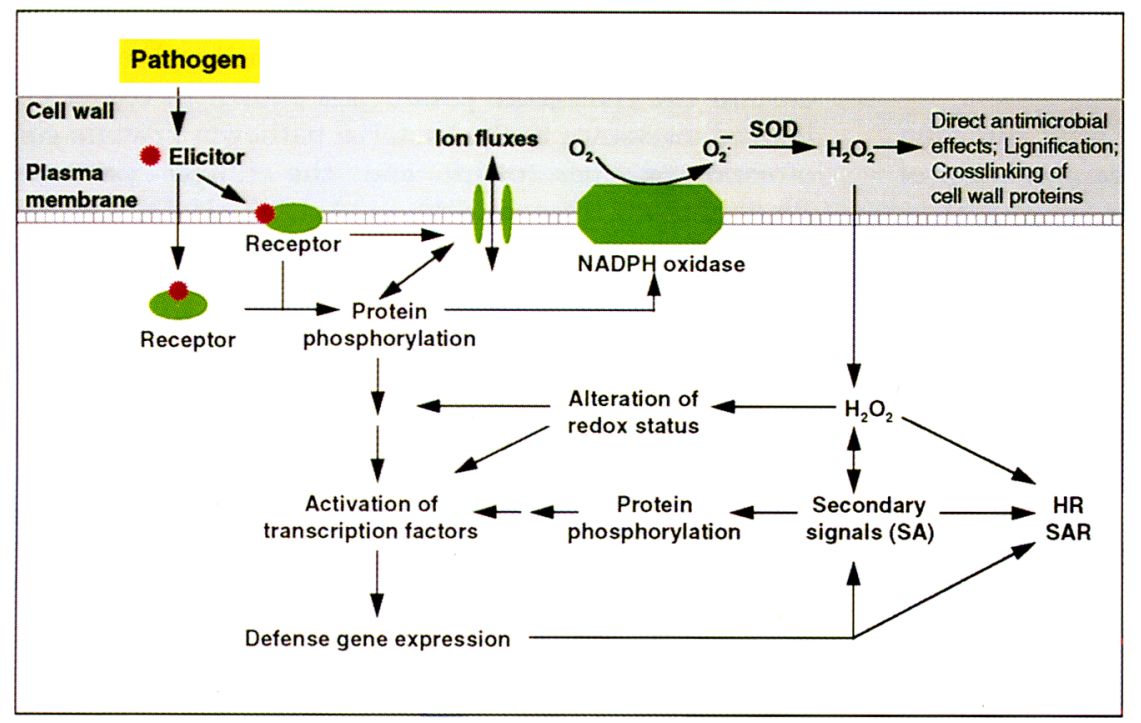

Figure 3. A simplified model for signal transduction in plant defense responses. Host recognition of pathogen elicitors initiates early signaling events such as protein phosphorylation/dephosphorylation, ion fluxes and oxidative burst. Subsequent transcriptional and/or posttranslational activation of transcription factors leads to induction of plant defense genes such as GST and PAL, and biosynthesis of endogenous secondary signals such as SA. In addition, the activated NADPH oxidase complex generates reactive oxygen species (ROS) such as $\mathrm{O}_{2} .^{-}$and $\mathrm{H}_{2} \mathrm{O}_{2}$ that alter the redox status of plant cells and affect defense signaling. SA, ROS, as well as defense genes, all contribute to the development of HR and SAR during plant-pathogen interactions. SOD, superoxide dismutase. 
berger et al. 1994; Atkinson et al. 1996). Conversely, $\mathrm{Ca}^{2+}$ ionophores or increases in extracellular $\mathrm{Ca}^{2+}$ level activated defense gene expression in tobacco (Suzuki et al. 1995), suggesting that $\mathrm{Ca}^{2+}$ plays an important role in signaling defense responses. In soybean cells, anion channel blockers have been shown to effectively inhibit the fungal elicitor-induced $\mathrm{Ca}^{2+} / \mathrm{H}^{+}$influxes and the expression of defense genes (Ebel et al. 1995).

Elicitor-induced ion fluxes are likely mediated by protein phosphorylation and dephosphorylation events. Protein kinase inhibitors, such as K252a, can block ion fluxes and medium alkalinization induced by fungal and bacterial elicitors (Felix et al. 1991; Popham et al. 1995). By contrast, treating tomato cells carrying the $C f 5$ resistance gene with the fungal Avr5 elicitor induced a phosphatase-catalyzed dephosphorylation of the plasma membrane $\mathrm{H}^{+}$-ATPase (Vera-Estrella et al. 1994a). This led to a significant increase in $\mathrm{H}^{+}$-ATPase activity and a subsequent acidification of the extracellular medium. Decreases in $\mathrm{H}^{+}-\mathrm{ATPase}$ activity by rephosphorylation were shown to be mediated by a $\mathrm{Ca}^{2+} /$ calmodulin-dependent kinase that in turn is activated by a $\mathrm{Ca}^{2+}$-dependent protein kinase C-like kinase (Xing et al. 1996). Thus, reversible phosphorylation appears to provide a mechanism to prevent prolonged stimulation of the $\mathrm{H}^{+}-$ ATPase, which could otherwise result in cell death. Interestingly, transgenic tobacco plants expressing a bacterial proton pump exhibited programmed cell death and induction of defense genes, consistent with the involvement of $\mathrm{H}^{+}$flux in signaling defense responses (Mittler et al. 1995). Furthermore, several fungal toxins have been known to target the plasma membrane $\mathrm{H}^{+}-\mathrm{ATPase}$. Fusicoccin, the major phytotoxin from the peach and almond pathogen Fusicoccum amygdali, stimulates $\mathrm{H}^{+}$ ATPase activity through modulation of its receptor, a member of the 14-3-3 superfamily of eukaryotic proteins (De Boer 1997). The fungal toxin NIPl from the barley pathogen Rhynchosporium secalis, which functions pleiotropically as a specific Avr elicitor on host plants carrying the Rrs1 resistance gene (Rohe et al. 1995), also activates the plasma membrane $\mathrm{H}^{+}-$ATPase (Wevelsiep et al. 1993). Therefore, perturbation of $\mathrm{H}^{+}$flux appears to be a common mode of action by virulent toxins and avirulent elicitors.

Another striking event occurring early after pathogen infection is the rapid production and accumulation of ROS, such as $\mathrm{O}_{2}{ }^{-}$and $\mathrm{H}_{2} \mathrm{O}_{2}$, known as the oxidative burst (Doke et al. 1996; Low and Merida 1996; Tenhaken et al. 1995). Elicitation of the oxidative burst by pathogen elicitors appears to be mediated by multiple signaling cascades and may be associated with the activation of $\mathrm{G}$ proteins, $\mathrm{Ca}^{2+}$ influx, $\mathrm{H}^{+} / \mathrm{K}^{+}$exchange, induction of phospholipases, and protein phosphorylation (Low and Merida 1996). The generation of ROS is likely dependent on the activation of a plasma membrane NADPH oxidase similar to that present in mammalian phagocytes. Specific inhibitors of the mammalian NADPH oxidase (e.g., diphenylene iodonium) prevent plant ROS induction by pathogen elicitors. Antibodies to various components of the mammalian NADPH oxidase cross-react with plant proteins of similar molecular mass (Dwyer et al. 1995; Tenhaken et al. 1995; Desikan et al. 1996). Moreover, a rice gene highly homologous to gp91phox, the main catalytic subunit of mammalian NADPH oxidase, has been isolated (Groom et al. 1996). Recently, specific Avr elicitors of $C$. fulvum were shown to increase NADPH oxidase activity by promoting the translocation of cytosolic components of the oxidase to the plasma membrane of tomato cells (Xing et al. 1997). This assembly process involves a $\mathrm{Ca}^{2+}$-dependent protein $\mathrm{ki}$ nase that phosphorylates cytosolic components of the oxidase and facilitates their translocation to the plasma membrane. In addition, $\mathrm{H}_{2} \mathrm{O}_{2}$ may also be produced by oxalate oxidases (Zhang et al. 1995b) and cell wall peroxidases (Bolwell et al. 1995) during plant defense responses.

Two distinct phases of ROS production have been observed during plant-pathogen interactions. The first burst occurs within minutes in both susceptible and resistant interactions, whereas the second, sustained burst occurs within a few hours of infection and only in a resistant interaction (Levine et al. 1994; Baker and Orlandi 1995). For example, Chandra et al. (1996) have shown recently that the second burst only occurs when tomato cells carrying the Pto resistance gene are challenged with $P$. syringae pv. tomato carrying avrPto. Either no burst or only a first burst is observed in the remaining three combinations of susceptible interactions, indicating that the second burst is correlated with racespecific resistance. However, the Pto kinase is not required for the oxidative burst initiated either by the nonhost pathogen $P$. syringae pv. tabaci (for which tomato is not a host for the growth of any races or pathovars of this pathogen) or by nonspecific elicitors such as oligogalacturonides. These results suggest the presence of multiple signaling cascades that activate the plasma membrane NADPH oxidase.

Superoxide anion and $\mathrm{H}_{2} \mathrm{O}_{2}$ generated during the oxidative burst play multiple roles in plant defense responses. During an HR, a highly localized accumulation of $\mathrm{H}_{2} \mathrm{O}_{2}$ was found in the lettuce cell walls adjacent to invading bacteria (Bestwick et al. 1997). In addition, constitutive expression of an $\mathrm{H}_{2} \mathrm{O}_{2}$-generating glucose oxidase in the transgenic potato was shown to confer enhanced resistance to the bacterial pathogen Erwinia carotovora pv. carotovora and the fungal pathogen Phytophthora infestans (Wu et al. 1995). $\mathrm{H}_{2} \mathrm{O}_{2}$ was also demonstrated to have direct antimicrobial activity (Peng and Kuc 1992) and to contribute to cell wall reinforcement by stimulating lignification and crosslinking of cell wall hydroxyproline-rich glycoproteins (Bradley et al. 1992; Brisson et al. 1994). Furthermore, superoxide anion and $\mathrm{H}_{2} \mathrm{O}_{2}$ may act as a secondary messenger to induce plant defense-related genes (Levine et al. 1994; Green and Fluhr 1995) and hypersensitive host cell death (Doke 1983a,b; Doke and Ohashi 1988; Levine et al. 1994; Dangl et al. 1996). Most recently, elicitor-stimulated superoxide anion from the oxidative burst was shown to be essential in triggering defense gene activation and phytoalexin synthesis in parsley (Jabs et al. 
1997). In mammals, transcription factors such as NF-кB and AP-1 are known to be redox regulated / Sen and Packer 1996). It is possible that ROS may activate defense gene expression by altering the redox status of plant cells, thereby modulating the activity of redox-sensitive transcription factors. In addition, $\mathrm{H}_{2} \mathrm{O}_{2}$ was shown to increase SA biosynthesis in tobacco by stimulating benzoic acid-2 hydroxylase activity (Léon et al. 1995). The action of ROS may also be mediated through changes in cytosolic $\mathrm{Ca}^{2+}$ levels and the generation of lipid peroxides (Price et al. 1994; León et al. 1995). Thus, although their mechanism(s) of action is poorly understood, ROS undoubtly play an important role in signaling plant defense responses.

GTP-binding proteins have also been suggested to participate in the induction of ion fluxes and the oxidative burst by some fungal elicitors (Legendre et al. 1992; VeraEstrella et al. 1994a,b; Xing et al. 1997). Further suggestion that GTP-binding proteins are associated with defense signaling has come from studies of tobacco transformed with the cholera toxin A1 subunit (Beffa et al. 1995). The A1 subunit irreversibly blocks the GTPase activity of $\mathrm{G}$ proteins, resulting in the sustained activation of the downstream signaling pathway. Transgenic plants expressing cholera toxin contained high levels of SA, expressed constitutively $P R$ genes, and exhibited enhanced resistance to a bacterial pathogen. Similarly, when a Ras-related, small GTP-binding protein was overexpressed in tobacco, wounding induced abnormal accumulation of SA, expression of acidic PR proteins, and enhanced resistance to TMV (Sano et al. 1994).

\section{Endogenous secondary signals in plant disease resistance}

\section{Salicylic acid}

Following the early signaling events activated by pathogen attack, the elicitor signals are often amplified through the generation of secondary signal molecules such as SA, ethylene, and jasmonates. A large body of evidence indicates that SA plays a critical role in the activation of defense responses. Increases in the levels of SA and its conjugates have been associated with the activation of resistance responses in a wide variety of plant species. These increases slightly precede or parallel the expression of $P R$ genes in both the infected tissue as well as the uninfected tissues exhibiting SAR (Malamy et al. 1990; Métraux et al. 1990; Rasmussen et al. 1991; Uknes et al. 1993; Summermatter et al. 1995; Dempsey et al. 1997). In addition, exogenous application of SA to tobacco and Arabidopsis induces the same set of PR genes as those activated during SAR development (Ward et al. 1991; Uknes et al. 1992, 1993).

Several studies have also demonstrated that when SA accumulation is prevented, resistance is compromised. Transgenic tobacco and Arabidopsis plants unable to accumulate SA because of the expression of the Pseudomonas putida nahG gene, which encodes salicylate hy- droxylase, exhibit poor induction of $P R$ genes after pathogen infection and fail to develop SAR (Gaffney et al. 1993; Delaney et al. 1994). In addition, these plants are more susceptible to primary infection by normally avirulent pathogens. This NahG phenotype appears to be caused specifically by the reduction in SA levels, since resistance could be restored by treatment with 2,6-dichloroisonicotinic acid (INA) or benzothiadiazole (BTH), two functional analogs of SA that are not substrates for salicylate hydroxylase (Delaney et al. 1994; Vernooij et al. 1995; Freidrich et al. 1996; Lawton et al. 1996). It also was demonstrated recently that inhibition of PAL, the first enzyme in the SA biosynthetic pathway, caused otherwise resistant Arabidopsis plants to become susceptible to avirulent strains of the fungal pathogen Peronospora parasitica. Resistance in these PAL-inhibited plants could be restored by the application of SA or INA (Mauch-Mani and Slusarenko 1996).

SA appears to be crucial for the activation of some of the defense responses, however it is currently unclear whether it is the long-distance signal that activates SAR in the uninoculated leaves. Grafting experiments have suggested that SA is not the mobile signal. Although NahG tobacco rootstocks fail to accumulate SA, they are able to generate a long-distance signal that activates SAR in the wild-type scion (grafted) leaves (Vernooij et al. 1994). In contrast, the demonstration that nearly $70 \%$ of the SA detected in the upper, uninoculated leaves of TMV-infected tobacco is transported from the inoculated leaf suggests that SA could be the mobile signal (Shulaev et al. 1995). Interestingly, recent experiments suggest that SAR may be induced by methyl salicylate, a volatile compound that is synthesized from SA in the inoculated leaf and converted back to SA in the uninoculated leaves (Shulaev et al. 1997). Further studies are clearly required to clarify SA's relationship to the long distance SAR signal.

Efforts to identify the SA receptor have led to the identification of several proteins that interact with SA (Durner et al. 1997). Most of these are either iron sulphur- or heme-containing proteins. The first SA-binding protein identified in tobacco was a catalase /Chen et al. 1993). The discovery that $\mathrm{SA}$ inhibited catalase's $\mathrm{H}_{2} \mathrm{O}_{2}$ degrading activity and $\mathrm{H}_{2} \mathrm{O}_{2}$-induced $P R$ gene expression led to the proposal that one mechanism of SA's action was to elevate the level of $\mathrm{H}_{2} \mathrm{O}_{2}$ or $\mathrm{H}_{2} \mathrm{O}_{2}$-derived ROS, which then serve as intermediates in the SA signaling pathway (Chen et al. 1993). Supporting this model was the observation that SA also inhibited the activity of ascorbate peroxidase, the other major $\mathrm{H}_{2} \mathrm{O}_{2}$-scavenging enzyme (Durner and Klessig 1995). Moreover, other inducers of resistance, namely INA and BTH, also inhibited catalase and ascorbate peroxidase activity (Conrath et al. 1995; D. Wendehenne, J. Durner, Z. Chen, and D.F. Klessig, in prep.).

In contrast, recent reports have provided evidence that defense responses, such as $P R-1$ induction during the $H R$ and SAR, are not activated by elevated $\mathrm{H}_{2} \mathrm{O}_{2}$ levels resulting from SA-mediated inhibition of catalase and ascorbate peroxidase. No decrease in catalase activity 
was detected in pathogen-inoculated leaves of tobacco and Arabidopsis plants (Bi et al. 1995; Summermatter et al. 1995|. In addition, the level of SA in uninfected tissues appears to be too low to effectively inhibit catalase and ascorbate peroxidase, and no increases in $\mathrm{H}_{2} \mathrm{O}_{2}$ were detected during the development of SAR (Bi et al. 1995). Furthermore, transgenic tobacco plants exhibiting drastically reduced catalase expression, attributable to cosuppression or synthesis of antisense RNA, failed to constitutively accumulate elevated levels of $P R-1$ mRNA or protein (Chamnongpol et al. 1996; Takahashi et al. 1997). Moreover, although $\mathrm{H}_{2} \mathrm{O}_{2}$ induced the expression of the $P R-1$ genes in wild-type tobacco leaves, it was ineffective in NahG plants (Bi et al. 1995; Neuenschwander et al. 1995). These results strongly argue that the elevated $\mathrm{H}_{2} \mathrm{O}_{2}$ levels produced by SA-mediated inhibition of catalase and ascorbate peroxidase do not directly activate defense responses. Rather, $\mathrm{H}_{2} \mathrm{O}_{2}$-activated expression of $P R-1$ appears to be mediated by SA. Indeed, application of $\mathrm{H}_{2} \mathrm{O}_{2}$, albeit at very high levels, induced SA synthesis in tobacco (León et al. 1995; Neuenschwander et al. 1995) as well as Arabidopsis (Summermatter et al. 1995).

Although SA-mediated inhibition of catalase and ascorbate peroxidase activity does not lead to $P R$ gene expression via elevated levels of $\mathrm{H}_{2} \mathrm{O}_{2}$, it may play other roles in the defense response. Inhibition of catalase and ascorbate peroxidase by the very high levels of SA found at infection sites may lead to increases in $\mathrm{H}_{2} \mathrm{O}_{2}$, which might initiate necrotic lesion formation by activating a cell death program. In addition, SA interaction with catalase and ascorbate peroxidase in the upper, uninoculated tissue may activate defense responses via the generation of free radicals. SA is thought to inhibit catalase and ascorbate peroxidase by serving as a one-electron-donating substrate; in the process, SA free radicals may be produced (Durner and Klessig 1996). Phenolic free radicals are potent initiators of both lipid peroxidation and protein oxidation. Increases in lipid peroxidation have been observed within and surrounding the HR induced by $C$. fulvum and TMV infection of tomato and tobacco, respectively (Hammond-Kosack and Jones 1996; May et al. 1996; M. Anderson, Z. Chen, and D.F. Klessig, unpubl.). Furthermore, lipid peroxides, the products of lipid peroxidation, were shown to induce $P R-1$ gene expression. Because lipid peroxidation is a self-perpetuating chain reaction, small amounts of SA free radical could be sufficient to activate defense responses in uninfected tissue without a readily discernible inhibition of catalase or ascorbate peroxidase activities.

Very recently, a $25-\mathrm{kD}$ soluble SA-binding protein termed SABP2 has been identified in tobacco leaves (Du and Klessig 1997). The affinity of SABP2 for SA $\left(K_{\mathrm{d}}=90\right.$ $\mathrm{nM})$ is $\sim 150$ times higher than that of catalase. Because it exhibits a greater affinity for SA and its biologically active analogs, as opposed to its inactive analogs, which do not induce $P R$ genes and enhanced resistance, SABP2 might play a role in SA-mediated disease resistance. Furthermore, SABP2 has a 15-fold greater affinity for the plant defense activator BTH than for SA. This is consis- tent with $\mathrm{BTH}^{\prime}$ s greater efficacy in inducing plant defense responses (Friedrich et al. 1996; Lawton et al. 1996; $\mathrm{Du}$ and Klessig 1997|. However, the role of SABP2 in disease resistance needs to be evaluated further using molecular genetic approaches.

Even though SA is required for resistance to many pathogens, SAR can develop independent of SA in some cases. In Arabidopsis, root inoculation with the bacteria $P$. fluorescens induces systemic resistance to Fusarium oxysporum as well as $P$. syringae pv. tomato in the absence of SA accumulation and SA-mediated $P R$ gene expression (Pieterse et al. 1996). Additionally, Cf2 or Cf9 gene-mediated resistance to $C$. fulvum in tomato does not appear to require SA accumulation, as resistance appears to be unaffected by presence of the nah $G$ gene (Hammond-Kosack and Jones 1996). Similarly, the systemic induction of several $P R$ genes in tobacco by the soft-rot pathogen Erwinia carotovora and the systemic induction of plant defensins /antimicrobial peptides that share homology with animal defensins such as drosomycin of the fruitfly) in Arabidopsis after Alternaria brassicicola infection occurred equally well in wild-type and NahG plants (Penninckx et al. 1996; Vidal et al. 1997).

\section{Ethylene, jasmonates, and systemin}

Besides SA, ethylene, jasmonic acid (JA), and systemin have also been implicated as important secondary signals for plant defense responses. Ethylene levels have been shown to increase during the HR (De Laat and Van Loon 1982; Enyedi et al. 1992; Hammond-Kosack and Jones 1996). Additionally, ethylene treatment induces the expression of $P A L$ and the basic $P R$ genes, as well as several wounding-induced genes (Boller et al. 1983; Mauch et al. 1984; Vogeli et al. 1988). Ethylene can also enhance the SA-induced expression of $P R-1$ in Arabidopsis (Lawton et al. 1994). Conversely, inhibitors of ethylene biosynthesis suppressed TMV-induced expression of $P R$ genes (Van Loon 1983) and ethylene action inhibitors blocked the SA-mediated expression of PR-3 proteins in tobacco (Raz and Fluhr 1992). By contrast, genetic evidence suggests that the induction of plant defense responses is ethylene independent. For example, the ethylene-insensitive Arabidopsis ein1, ein2, and etr1 mutants exhibit wild-type levels of resistance to pathogen attack (Bent et al. 1992; Lawton et al. 1995).

The activation of defense responses after mechanical wounding and insect attack appears to be mediated by systemin, an 18-amino-acid peptide, as well as by JA and its ester, methyl jasmonate (MeJA), collectively termed jasmonates. Jasmonates are produced from the major plant plasma membrane lipid linolenic acid via the octadecanoid biosynthetic pathway. This pathway is analogous to the eicosanoid pathway in which the major animal plasma membrane lipid arachidonic acid is converted to prostaglandins, leukotrienes, and related compounds that often mediate localized stress responses in animal cells. Wounding, systemin, and jasmonates induce the expression of proteinase inhibitors (PI) I and II, PAL, and JIP60 (Pearce et al. 1991; Farmer and Ryan 
1992; Gundlach et al. 1992; Reinbothe et al. 1994a). The PI proteins reduce herbivory and insect attack by inhibiting key degradative enzymes, whereas JIP60 has been proposed to reduce pathogen attack by mediating polysome dissociation (Reinbothe et al. 1994b). Transgenic tomato plants with lowered systemin expression, due to antisense inhibition, were shown to accumulate significantly less PI protein after wounding (McGurl et al. 1992). In addition, the systemin-induced accumulation of PI proteins in tomato could be blocked by inhibition of JA or MeJA biosynthesis (Farmer et al. 1994). Based on these results, the signal-activating wounding defenses appear to be transduced initially through systemin and subsequently through the octadecanoid biosynthetic pathway.

Several lines of evidence suggest the presence of cross talk between the SA, ethylene, and systemin/jasmonate defense signaling pathways. For example, in tobacco overexpressing the rice rgp1 gene, which encodes a Rasrelated, small GTP-binding protein, or the tobacco WIPK gene, which encodes a MAPK, wounding causes the aberrant accumulation of SA and $P R$ mRNAs. In contrast, these responses are not induced by wounding untransformed plants (Sano et al. 1994; Seo et al. 1995). The most striking evidence for cross talk, however, comes from a phenomenon known as potentiation. Potentiation occurs when the signals associated with one defense pathway positively affect the magnitude and kinetics of defense responses associated with a different pathway. Several elicitor- and wounding-induced defense responses, including $\mathrm{H}_{2} \mathrm{O}_{2}$ production, $P A L$ expression, and cell death, can be potentiated by levels of SA that, by themselves, are too low to induce these effects /Kauss et al. 1992; Fauth et al. 1996; Mur et al. 1996; Shirasu et al. 1997). Similarly, ethylene can potentiate the SA-mediated induction of PR-1 gene expression in Arabidopsis (Lawton et al. 1994). The simultaneous treatment of tobacco seedlings with SA and MeJA has also been shown to superinduce the accumulation of $P R-1$ transcript compared to that observed with SA or MeJA alone (Xu et al. 1994). However, the significance of this potentiation is unclear since aspirin (and hence probably SA) blocks JA biosynthesis and activity (Peña-Cortés et al. 1993; Doares et al. 1995a,b). Future analyses using the jasmonateand ethylene-insensitive mutants of Arabidopsis (Guzman and Ecker 1990; Feys et al. 1994; Ecker 1995) should help define the role these compounds have in both local and systemic resistance to microbial pathogens.

\section{Integration of signaling pathways and activation of plant defense genes}

The initial perception and early signal transduction events may be distinct for various pathogen elicitors. However, many of these signals are probably integrated into one of a few terminal pathways that lead to the transactivation steps involved in the interaction between activated transcription factors and pathogen-responsive cis elements in the promoters of defense genes.
A single pathogen elicitor may activate multiple transcription factors that interact with different cis elements in the same or different promoters, leading to induction of many defense genes. Several pathogen-responsive cis elements have been identified and the corresponding DNA-binding proteins isolated (Zhu et al. 1996). Some of these transcription factors are transcriptionally and/or post-translationally activated by pathogen infection or treatment with secondary signals, such as SA.

A number of plant defense genes (e.g., maize PRms, asparagus $A O P R 1$, and potato $P R-10 a$ ) contain an elicitorresponsive TTGACC element (Raventós et al. 1995). This element is also present as the $\mathrm{W}$ boxes in the parsley $P R-1$ gene promoter (Meier et al. 1991; note: parsley $P R-1$ is not related to tobacco $P R-1$, rather it belongs to the $P R-10$ family of intracellular $P R$ genes that are wound-inducible). Three parsley cDNA clones encoding the W-box binding proteins have been isolated by Southwestern screening (Rushton et al. 1996). These proteins contain zinc finger motifs and belong to the WRKY family of plant transcription factors. Their mRNA levels were up- or down-regulated on treatment with a fungal protein elicitor, suggesting that they play a role in signaling parsley $P R-1$ gene activation.

Transcription of the parsley $P R-2$ gene is stimulated rapidly by fungal or bacterial elicitors and mediated by an 11-bp cis element (CTAATTGTTTA) present in its promoter. The cDNA clones encoding a homeodomain protein that specifically binds to this element have been isolated from both parsley and Arabidopsis (Korfhage et al. 1994). This homeodomain protein may be involved in transcriptional regulation of the parsley $P R-2$ gene.

A 10-bp TCA (TCATCTTCTT) element is present in the promoters of many stress-inducible genes, including tobacco PR genes (Goldsbrough et al. 1993). A 40-kD tobacco nuclear protein binds to this TCA element in an SA-dependent manner. However, this TCA element was neither sufficient nor required for SA-mediated induction of the tobacco PR-2d promoter in vivo (Shah and Klessig 1996). By contrast, a 25-bp SA-responsive element was identified by in vivo analysis of the $P R-2 d$ promoter. This element contains the sequence TCGACC, which is similar to the elicitor-responsive TTGACC element found in the parsley $P R-1$ promoter. As the induction of TTGACC element-containing genes by pathogens, elicitors, or wounding is potentiated by SA pretreatment, related factors such as members of WRKY family might be involved in SA activation of the tobacco $P R-2 d$ gene.

Another SA-responsive element is the activator sequence-1 (as-1 or ocs), which was identified initially in the $35 \mathrm{~S}$ promoter of cauliflower mosaic virus (CaMV), and the nos and ocs (two opine synthase genes) promoters of Agrobacterium, respectively (Ellis et al. 1987; Bouchez et al. 1989; Lam et al. 1989). The as-1 element was also found in the promoters of stress-induced plant genes such as GST (Ellis et al. 1993; Ulmasov et al. 1994; Chen et al. 1996; van der Zaal et al. 1996), and it rapidly responds to various signals, including SA, auxin, jasmonates, and $\mathrm{H}_{2} \mathrm{O}_{2}$ (Kim et al. 1993; Qin et al. 1994; Ulma- 
sov et al. 1994, 1995; Zhang and Singh 1994). Several members of the TGA family of bZIP transcription factors have been isolated from tobacco and Arabidopsis and shown to bind the as-1 element (Katagiri et al. 1989; Zhang et al. 1993; Miao et al. 1994). Transgenic plant analyses have also linked TGA transcription factors with as-1 element activity (Neuhaus et al. 1994; Rieping et al. 1994). A zinc finger DNA-binding protein from Arabidopsis was found to bind to a distinct site next to the as-1 element in the $35 S$ promoter; binding of this protein significantly enhanced the as-1 binding activity of TGA factors (Zhang et al. 1995a). In addition, as-1 binding activity appears to be regulated by the phosphorylation status of the binding factor(s) and/or an inhibitory protein (Jupin and Chua 1996).

The promoters of many ethylene-inducible $P R$ genes (e.g., basic $P R-1, P R-2$, and $P R-3$ ) contain a conserved ethylene-responsive 11-bp GCC box (TAAGAGCCGCC; Eyal et al. 1993). Tobacco ethylene-responsive element binding proteins (EREBPs) have been isolated and shown to bind specifically to the GCC box sequence /OhmeTakagi and Shinshi 1995). The expression of EREBP mRNAs is induced by ethylene, but individual EREBPs exhibit different patterns of expression. Recently, several tomato proteins, which interact with the kinase encoded by the $P$ to resistance gene, were shown to share extensive homology with the EREBPs and specifically bind to the GCC box. Thus, there may be a direct link between specific recognition by an $R$ gene product, protein phosphorylation, and transcriptional activation of plant defense genes (Zhou et al. 1997). Interestingly, tobacco EREBPs and tomato Pti4/5/6 are homologous to the homeotic protein APETALA2 that controls flower and seed development in Arabidopsis (Jufuku et al. 1994).

A ubiquitous cis element present in many plant genes is the G box (CACGTG), which is bound by the GBF (G box binding factor) family of bZIP transcription factors (Menkens et al. 1995). The G box is also present in the promoters of several plant defense genes such as $P A L$ and CHS, and is thought to mediate responses to diverse environmental stimuli including light, elicitors, and redox changes. The $\mathrm{H}$ box (CCTACC) is another elicitor-responsive cis element frequently found in the promoters of phenylpropanoid biosynthetic genes such as $P A L$ and CHS. Two $\mathrm{H}$ box binding proteins (KAP-1 and KAP-2) have been purified from bean suspension cultures (Yu et al. 1993). Elicitation with glutathione does not affect the overall activity of KAP-1 or KAP-2 in the cells. However, there is a rapid increase in the specific activities of both factors in the nuclear fraction, suggesting that they are translocated to the nucleus after elicitation, where they may play a role in the activation of defense genes. Recently, a soybean bZIP transcription factor called G/HBF-1 was isolated and shown to bind both the G box and an adjacent $\mathrm{H}$ box in the proximal region of the bean chs15 promoter (Dröge-Laser et al. 1997). Although its mRNA and protein levels do not increase during the induction of defense genes, G/HBP-1 is rapidly phosphorylated in elicited soybean cells. Phosphorylation of $\mathrm{G} / \mathrm{HBP}-1$ in vitro also enhances binding to the chs 15 promoter, suggesting its involvement in the activation of plant defense genes.

Interestingly, the $\mathrm{H}$ and $\mathrm{G}$ boxes are very similar to Myb- and Myc-binding sites, respectively, and can be recognized by the plant Myb- and Myc-like transcription factors involved in phenylpropanoid biosynthesis (Grotewold et al. 1994; Sablowski et al. 1994). Recently, a TMV-inducible myb gene $\{m y b 1\}$ was isolated from tobacco (Yang and Klessig 1996). Expression of this gene was activated rapidly (within $15 \mathrm{~min}$ ) by exogenous SA, and its activation preceeded induction of the acidic $P R-1$ genes. Tobacco PR-1 gene promoters contain both Myband Myc-binding sites. The recombinant Mybl protein was able to specifically bind to an $\mathrm{H}$ box-like Myb-binding site present in the promoter of the $P R-1 a$ gene. These results suggest that the tobacco $m y b 1$ gene encodes a signaling component downstream of SA that may participate in transcriptional activation of $P R$ genes and plant disease resistance. As is the case for several of the transcription factors mentioned above, the role of Mybl in activation of plant defense genes remains to be rigorously established using in vivo assays, such as transgenic plant analysis.

\section{Genetic approaches to dissect signaling pathways for plant defense responses}

Mutational analysis has been a powerful tool for identifying the components of various signaling pathways in organisms as diverse as yeast, Caenorhabditis elegans, and Drosophila. Among plants, the crucifer Arabidopsis thaliana serves as an excellent model organism to identify mutants with altered defense responses (Dangl et al. 1996; Ryals et al. 1996). Currently, mutations in Arabidopsis that either constitutively activate defense responses (acd2, 1sd, cpr1, cep1, cim3; Bowling et al. 1994; Detrich et al. 1994; Greenberg et al. 1994; Weymann et al. 1995; Klessig et al. 1996; Ryals et al. 1996) or compromise defense responses (npr1, nim1, sai1, ndr1, pad4, eds; Cao et al. 1994; Century et al. 1995; Delaney et al. 1995; Glazebrook et al. 1996, 1997; Parker et al. 1996; Shah et al. 1997) have been identified using various genetic screens.

All of the Arabidopsis mutants with constitutively activated defense responses accumulate elevated levels of SA, express elevated levels of $P R$ genes, and exhibit enhanced resistance to pathogens (Table 1). In addition, acd2, cep1, and the 1sd group of mutants develop spontaneous lesions that resemble an HR (Dietrich et al. 1994; Greenberg et al. 1994; Weymann et al. 1995; H. Silva and D.F. Klessig, unpubl.). The constitutive expression of $P R$ genes and the enhanced resistance phenotypes of the $1 s d, c p r 1, c e p 1$, and cim 3 mutants were shown to require constitutively elevated levels of $\mathrm{SA}$, as they were suppressed by the nahG-encoded salicylate hydroxylase (Bowling et al. 1994; Weymann et al. 1995; Dangl et al. 1996; Ryals et al. 1996; H. Silva and D.F. Klessig, unpubl.). However, expression of nahG suppressed the spontaneous lesion phenotype only in $1 s d 1,1 s d 6$, and $1 s d 7$ and not in $1 s d 2$ and $1 s d 4$ (Weymann et al. 1995; 
Table 1. A. thaliana mutants with altered disease resistance

\begin{tabular}{|c|c|c|c|c|}
\hline Mutant $^{\mathrm{a}}$ & $\begin{array}{l}\text { Dominant/ } \\
\text { recessive }\end{array}$ & SA levels ${ }^{\mathrm{b}}$ & Comments & References \\
\hline $\begin{array}{l}\text { npr1/sai1/nim1/ } \\
\text { eds-5/eds-53 }\end{array}$ & recessive & normal & $\begin{array}{l}\text { allelic; SA/INA/BTH insensitive; enhanced } \\
\text { susceptibility to avirulent pathogens; } \\
\text { normal HR; Nprl contains ankyrin } \\
\text { repeats and shares some homology with } \\
\text { IкB }\end{array}$ & $\begin{array}{l}\text { Cao et al. }(1994,1997) ; \\
\text { Delaney et al. }(1995) ; \\
\text { Ryals et al. }(1997) ; \\
\text { Shah et al. }(1997)\end{array}$ \\
\hline$n d r 1$ & recessive & N.D. & $\begin{array}{l}\text { INA responsive; enhanced susceptibility to } \\
\text { pathogens; normal HR to most avirulent } \\
\text { pathogens }\end{array}$ & Century et al. (1995) \\
\hline eds1 & recessive & N.D. & $\begin{array}{l}\text { INA responsive; enhanced susceptibility to } \\
\text { pathogens }\end{array}$ & Parker et al. (1996) \\
\hline $\begin{array}{l}\text { eds-9(pad4), } \\
\quad \text { eds-47(pad2) }\end{array}$ & recessive & N.D. & $\begin{array}{l}\text { nonallelic; SA responsive; enhanced } \\
\text { susceptibility to pathogens; deficient in } \\
\text { camalexin accumulation }\end{array}$ & $\begin{array}{l}\text { Glazebrook et al. (1996, } \\
\text { 1997) }\end{array}$ \\
\hline $\begin{array}{l}\text { eds-2,-4,-6,-8,-40, } \\
-42 \text { and }-48\end{array}$ & recessive & N.D. & $\begin{array}{l}\text { nonallelic; SA responsive; enhanced } \\
\text { susceptibility to pathogens }\end{array}$ & Glazebrook et al. (1996) \\
\hline $\begin{array}{l}\text { acd2, cep1, lds1, } \\
1 s d 3, \text { and } 1 s d 5\end{array}$ & recessive & elevated & $\begin{array}{l}\text { constitutively high expression of PR genes; } \\
\text { develop spontaneous lesions and have } \\
\text { enhanced resistance to pathogens; nahG } \\
\text { suppresses all } 1 s d 1 \text { phenotypes; } a c d 2,1 s d 1 \text {, } \\
1 s d 3 \text {, and } 1 s d 5 \text { are nonallelic; cep } 1 \text { is } \\
\text { nonallelic to acd2 }\end{array}$ & $\begin{array}{l}\text { Dietrich et al. (1994); } \\
\text { Greenberg et al. (1994); } \\
\text { Klessig et al. (1996); } \\
\text { Dangl et al. (1996); } \\
\text { H. Silva and D.F. Klessig } \\
\text { (unpubl.) }\end{array}$ \\
\hline $\begin{array}{l}1 s d 2,1 s d 4,1 s d 6 \\
\quad \text { and } 1 s d 7\end{array}$ & dominant & elevated & $\begin{array}{l}\text { nonallelic; constitutively high expression of } \\
\text { PR genes; develop spontaneous lesions } \\
\text { and have enhanced resistance to } \\
\text { pathogens; all mutant phenotypes } \\
\text { suppressed by nah } G \text { in } 1 s d 6 \text { and } 1 s d 7 \text {; only } \\
\text { SAR phenotype suppressed by nah } G \text { in } \\
\text { lsd2 and } 1 s d 4\end{array}$ & $\begin{array}{l}\text { Dietrich et al. (1994); } \\
\text { Weymann et al. (1995) }\end{array}$ \\
\hline cpr1 & recessive & elevated & $\begin{array}{l}\text { constitutively high expression of PR genes; } \\
\text { no spontaneous lesions; mutant } \\
\text { phenotype suppressed by nahG }\end{array}$ & Bowling et al. (1994) \\
\hline $\operatorname{cim} 3$ & dominant & elevated & $\begin{array}{l}\text { constitutively high expression of PR genes; } \\
\text { no spontaneous lesions; mutant } \\
\text { phenotype suppressed by nahG }\end{array}$ & Ryals et al. (1996) \\
\hline
\end{tabular}

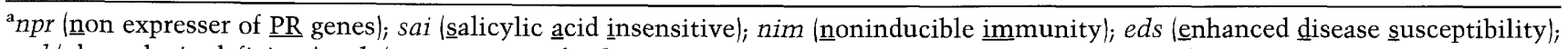
pad (phytoallexin deficient); $n d r$ (non-race-specific disease resistance); acd (accelerated cell death); $1 s d$ (lesion-simulating disease); $c p r$ (constitutive expressor of $\underline{\mathrm{PR}}$ genes); cep (constitutive expression of $\underline{\mathrm{PR}}$ genes); cim (constitutive immunity).

$\mathrm{b}$ (N.D.) Not determined.

Dangl et al. 1996; Ryals et al. 1996). Thus, lesion formation may be induced through multiple pathways. Furthermore, lesion formation appears to be regulated by a feedback loop since it was restored in nahG-expressing Isd1 and 1sd6 mutants by the application of INA (Weymann et al. 1995; Dangl et al. 1996).

Although elevated SA levels have a causal role in the enhanced resistance observed in the above mutants, it is unclear whether they are a result of mutations in genes that participate in the resistance signaling pathway. Alternatively, the increase in SA levels may be caused by mutations in SA biosynthetic genes, or they may be a nonspecific response to stress. It was recently demonstrated that the leaves of $1 s d 1$ plants accumulate elevated levels of superoxide prior to the development of spontaneous lesions (Jabs et al. 1996). Furthermore, lesion formation could be induced by injecting $l_{s} d 1$ leaves with a superoxide-generating system; this treatment did not cause lesions on the leaves of wild-type plants. As lesion formation could be prevented by simultaneously injecting $1 s d 1$ leaves with the superoxide-generating system and superoxide dismutase, these plants may be deficient in some factor or signal that regulates the accumulation of and/or response to superoxide and thereby prevents runaway cell death. The LSD1 gene has been cloned recently (Dietrich et al. 1997). The predicted protein contains three zinc finger domains, suggesting that it may be a transcription factor that negatively regulates the cell death pathway.

Metabolic stress generated by the inappropriate expression/repression of a wide variety of genes in plants can also lead to phenotypes similar to those of the Arabidopsis $1 s d$ mutants. Transgenic tobacco expressing either the bacterio-opsin gene, which encodes a bacterial proton pump, or a mutant derivative of ubiquitin, which interferes with ubiquitin-dependent proteolysis, develop 
spontaneous HR-like lesions, show enhanced resistance to pathogens, accumulate high levels of SA, and constitutively express $P R$ genes (Becker et al. 1993; Mittler et al. 1995). These same characteristics were also observed in transgenic tobacco expressing a subunit of cholera toxin or a yeast vacuolar invertase gene (Beffa et al. 1995; Herbers et al. 1996). Thus, identifying the biochemical and physiological alterations in these transgenic plants and the Arabidopsis mutants, as well as cloning the respective Arabidopsis genes, should provide new information about the signaling components through which SA-mediated disease resistance can be activated.

A variety of Arabidopsis mutants whose resistance to pathogens is compromised have also been identified. The ndr1 mutant was identified by screening for loss of resistance to an avirulent pathogen, whereas the eds group of mutants was identified in screens that permitted enhanced pathogen growth (Century et al. 1995; Glazebrook et al. 1996; Parker et al. 1996). Except for eds5 and eds53, which are allelic with npr1, sail and nim 1 (Glazebrook et al. 1996; Cao et al. 1997; Ryals et al. 1997; Shah et al. 1997), the remaining eds mutants and ndr1 exhibit normal SA/INA inducibility of $P R$ gene expression and hence are not defective in SA signaling (Glazebrook et al. 1996; Parker et al. 1996; Ryals et al. 1996). The NDR1 and EDS genes may encode components of other signal transduction pathways involved in pathogen recognition. Alternatively, they may encode proteins involved in the synthesis of antimicrobial compounds. For example, the eds9 (pad4) and eds47 (pad2-2) mutants are defective in the accumulation of the phytoalexin camalexin (Glazebrook et al. 1996, 1997).

The allelic npr1, sai1, and nim 1 mutants, by contrast, were identified initially by their insensitivity to SA or INA (Cao et al. 1994; Delaney et al. 1995; Shah et al. 1997). These mutants fail to express $P R$ genes at high levels after SA treatment and exhibit increased susceptibility to bacterial and fungal pathogens (Cao et al. 1994; Delaney et al. 1995; Shah et al. 1997). Additionally, mutants containing the nim 1-1 and sai1-1 alleles were shown to be nonresponsive to INA and BTH (Lawton et al. 1996; Shah et al. 1997). This finding correlates with the available biochemical evidence suggesting that these compounds are functional analogs of SA that induce defense responses via the SA signaling pathway (Conrath et al. 1995; Durner and Klessig 1995; Vernooij et al. 1995; Görlach et al. 1996; Malamy et al. 1996; Du and Klessig 1997; D. Wendehenne, J. Durner, Z. Chen, and D.F. Klessig, in prep.l.

The recessive nature of the various mutant npr 1 alleles suggests that NPR1 encodes a positive regulator of the SA signal transduction pathway (Delaney et al. 1995; Cao et al. 1997; Shah et al. 1997). Furthermore, NPR1 appears to act downstream of SA in the defense signaling pathway, since the npr1 mutants do not respond to exogenous SA and the sai1-1 and nim 1-1 mutants accumulate elevated levels of SA upon pathogen infection (Delaney et al. 1995; Shah et al. 1997). Interestingly, the levels of SA detected in the sai1-1 mutants after infection with $P$. syringae pv. syringae were 10-15 times higher than those seen in wild-type plants, which provides additional evidence that $\mathrm{SA}$ accumulation is normally under feedback regulation (Shah et al. 1997).

The NPR1 gene was cloned recently and shown to encode a $60-\mathrm{kD}$ protein with ankyrin repeats and some homology to the mammalian IкB protein (Cao et al. 1997; Ryals et al. 1997). The significance of the ankyrin repeats in Nprl function is highlighted by the demonstration that a histidine to tyrosine alteration in the third ankyrin repeat is responsible for the npr1-1 mutant phenotype (Cao et al. 1997). In mammals, ankyrin repeats have been demonstrated to participate in protein-protein interactions, such as those between IкB and NF- $\mathrm{B}$ or 53BP2 with the tumor suppressor p53 (Gorina and Pavletich 1996; Krappmann et al. 1996). By analogy, Npr1 may interact with another protein(s) to transduce the SA signal.

\section{Conclusions}

A combination of genetic, molecular, and biochemical approaches have led to important new insights into the signal perception and transduction processes in plant defense responses. The recent cloning of plant disease resistance genes, in particular, has greatly advanced our understanding of the recognition and perception mechanisms involved in race-specific disease resistance. The striking conservation of certain motifs, such as LRRs, among nearly all cloned $R$ genes responsible for recognizing diverse plant pathogens, suggests that a prevalent mechanism of signal recognition may underlie the genefor-gene specificity. Although initial perception mechanisms may differ, many pathogen elicitors appear to trigger a common network of signaling pathways that coordinate the overall defense responses. Such signaling processes involve protein phosphorylation, ion fluxes, cellular redox modulation, secondary signal amplication, and transcriptional activation of plant defense genes. Intriguingly, many signaling components, such as Toll/ interleukin-1 receptor-like domain, G proteins, NADPH oxidase, $\mathrm{H}_{2} \mathrm{O}_{2}$, MAP kinases, $\mathrm{I} \kappa \mathrm{B}$, and $\mathrm{Myb}$ transcription factors, appear to be conserved in higher eukaryotes and may mediate host defense responses in both animal and plant systems. Even antimicrobial peptides such as plant defensins and some pathogenesis-related proteins such as $P R-1$ are conserved in eukaryotes as components of host defense systems (Fang et al. 1988; Broekaert et al. 1995; Murphy et al. 1995). Recently, the plant hypersensitive cell death triggered by pathogen attack was shown to share many of the cytological and biochemical characteristics associated with animal programmed cell death which is involved in not only development, but also elimination of transformed or infected cells (Dangl et al. 1996; Greenberg 1996). Therefore, elucidation of plant defense signaling mechanisms should provide crucial information to enhance our understanding of hostpathogen interactions in general, as well as to develop new strategies for plant disease control. 


\section{Acknowledgments}

We thank colleagues who kindly provided reprints or preprints of their studies. We thank D'Maris Dempsey for critical reading of the manuscript. The authors' studies described in this review were supported by grants MCB 9310371 and MCB 9514239 from the National Science Foundation to D.F.K. Y. Y. was supported in part by a Charles Johanna Busch postdoctoral fellowship from the Waksman Institute.

\section{References}

Alfano, J.R. and A. Collmer. 1996. Bacterial pathogens in plants: Life up against wall. Plant Cell 8: 1683-1698.

Anderson, P.A., G.J. Lawrence, B.C. Morrish, M.A. Ayliffe, E.J. Finnegan, and J.G. Ellis. 1997. Inactivation of the flax rust resistance gene $M$ associated with loss of a repeated unit within the leucine-rich repeat coding region. Plant Cell 9: 641-651.

Atkinson, M.M., L.D. Keppler, E.W. Orlandi, C.J. Baker, and C.F. Mischke. 1990. Involvement of plasma membrane calcium influx in the bacterial induction of the $\mathrm{K}^{+} / \mathrm{H}^{+}$and hypersensitive response in tobacco. Plant Physiol. 92: 215-221.

Atkinson, M.M., S.L. Midland, J.J. Sims, and N.T. Keen. 1996. Syringolide 1 triggers $\mathrm{Ca}^{+}$influx, $\mathrm{K}^{+}$efflux, and extracellular alkalization in soybean cells carrying the disease resistance gene Rpg4. Plant Physiol. 112: 297-302.

Bach, M., J-P. Schnitzler, and H. Ulrich. 1993. Elicitor-induced changes in $\mathrm{Ca}^{+}$influx, $\mathrm{K}^{+}$efflux, and 4-hydroxybenzoic acid synthesis in protoplasts of Daucus carota. Plant Physiol. 103: $407-412$

Baker, B., P. Zambryski, B. Staskawicz, and S.P. Dinesh-Kumar. 1997. Signaling in plant-microbe interactions. Science 276: 726-733.

Baker, C.J. and E.W. Orlandi. 1995. Active oxygen in plant pathogenesis. Annu. Rev. Phytopathol. 33: 299-321.

Becker, F., E. Buschfeld, J. Schell, and A. Bachmair. 1993. Altered response to viral infection by tobacco plants perturbed in ubiquitin system. Plant $J$. 3: 875-881.

Beffa, R., M. Szell, P. Meuwly, A. Pay, R. Vogeli-Lange, J.-P. Métraux, G. Neuhaus, F. Meins, and F. Nagy. 1995. Cholera toxin elevates pathogen resistance and induces defense reactions in transgenic tobacco plants. EMBO J. 14: 5753-5761.

Benhamou, N. 1996. Elicitor-induced plant defense pathways. Trends Plant Sci. 1: 233-240.

Bent, A.F. 1996. Plant disease resistance genes: Function meets structure. Plant Cell 8: 1757-1771.

Bent, A.F., R.W. Innes, J.R. Ecker, and B.J. Staskawicz. 1992. Disease development in ethylene-insensitive Arabidopsis thaliana infected with virulent and avirulent Pseudomonas and Xanthomonas pathogens. Mol. Plant-Microbe Interact. 5: $372-378$.

Bent, A.F., B.N. Kunkel, D. Dahlbeck, K.L. Brown, R.L. Schmidt, L. Giraudat, J.L. Leung, and B.J. Staskawicz. 1994. RPS2 of Arabidopsis thaliana: A leucine-rich repeat class of plant disease resistance gene. Science 265: 1856-1860.

Bestwick, C.S., I.R. Brown, M.H.R. Bennett, and J.W. Mansfield. 1997. Localization of hydrogen peroxide accumulation during the hypersensitive reaction of lettuce cells to Pseudomonas syringae pv. phaseolicola. Plant Cell 9: 209-221.

Bi, Y.-M., P. Kenton, L. Mur, R. Darby, and J. Draper. 1995. Hydrogen peroxide does not function downtream of salicylic acid in the induction of $\mathrm{PR}$ protein expression. Plant $J$. 8: 235-246.

Boller, T., A. Gehri, F. Mauch, and U. Vögeli. 1983. Chitinase in bean leaves: Induction by ethylene, purification, properties, and possible function. Planta 157: 22-31.

Bolwell, G.P., V.S. Butt, D.R. Davies, and A. Zimmerlin. 1995. The origin of the oxidative burst in plants. Free Rad. Res. Comm. 23: 517-532.

Bouchez, D., J.G. Tokuhisa, D.J. Llewellyn, E.S. Dennis, and J.G. Ellis. 1989. The ocs-element is a component of the promoters of several T-DNA and plant viral genes. EMBO J. 8: 41974204.

Bowling, S.A., A. Guo, H. Cao, A.S. Gordon, D.F. Klessig, and X. Dong. 1994. A mutation in Arabidopsis that leads to constitutive expression of systemic acquired resistance. Plant Cell 6: $1845-1857$.

Bradley, D.J., P. Kjellbom, and C.J. Lamb. 1992. Elicitor- and wound-induced oxidative cross-linking of a proline-rich plant cell wall protein: A novel, rapid defense response. Cell 70: 21-30.

Brears, T. and J. Ryals. 1994. Genetic engineering for disease resistance in plants. Agro-Food-Industry Hi-Tech. July/Aug.: $10-13$.

Brisson, L.F., R. Tenhaken, and C. Lamb. 1994. Function of oxidative cross-linking of cell wall structural proteins in plant disease resistance. Plant Cell 6: 1703-1712.

Broekaert, W.F., F.R.G. Terras, B.P.A. Cammue, and R.W. Osborn. 1995. Plant defensins: Novel antimicrobial peptides as components of the host defense system. Plant Physiol. 108: $1353-1358$.

Cao, H., S.A. Bowling, A.S. Gordon, and X. Dong. 1994. Characterization of an Arabidopsis mutant that is nonresponsive to inducers of systemic acquired resistance. Plant Cell 6: $1583-1592$.

Cao, H., J. Glazebrook, J.D. Clarke, S. Volko, and X. Dong. 1997. The Arabidopsis NPR1 gene that controls systemic acquired resistance encodes a novel protein containing ankyrin repeats. Cell 88: 57-63.

Century, K.S., E.B. Houlb, and B.J. Staskawicz. 1995. NDR1, a locus of Arabidopsis thaliana that is required for disease resistance to both a bacterial and a fungal pathogen. Proc. Natl. Acad. Sci. 92: 6597-6601.

Chamnongpol, S., H. Willekens, C. Langebartels, M.V. Montagu, D. Inzé, and W.V. Camp. 1996. Transgenic tobacco with a reduced catalase activity develops necrotic lesions and induces pathogenesis-related expression under high light. Plant I. 10: 491-503.

Chandra, S., G.B. Martin, and P.S. Low. 1996. The Pto kinase mediates a signaling pathway leading to the oxidative burst in tomato. Proc. Nat1. Acad. Sci. 93: 13393-13397.

Chen, W., G. Chao, and K.B. Singh. 1996. The promoter of a $\mathrm{H}_{2} \mathrm{O}_{2}$-inducible, Arabidopsis glutathione S-transferase gene contains closely linked OBF- and OBP1-binding sites. Plant J. 10: 955-966.

Chen, Z., H. Silva, and D.F. Klessig. 1993. Active oxygen species in the induction of plant systemic acquired resistance by salicylic acid. Science 262: 1883-1886.

Conrath, U., H. Silva, and D.F. Klessig. 1997. Protein dephosphorylation mediates salicylic acid-induced expression of PR-1 genes in tobacco. Plant T. 11: 747-757.

Conrath, U., Z. Chen, J. Ricigliano, and D.F. Klessig. 1995. Two inducers of plant defense responses, 2,6,-dichloroisonicotinic acid and salicylic acid, inhibit catalase activity in tobacco. Proc. Nat1. Acad. Sci. 92: 7143-7147.

Dangl, J.L. 1994. The enigmatic avirulence genes of phytopathogenic bacteria. Curr. Top. Microbiol. Immunol. 192: 99-118.

Dangl, J.L., R.A. Dietrich, and M.H. Richberg. 1996. Death don't have no mercy: Cell death programs in plant-microbe interactions. Plant Cell 8: 1793-1807. 
De Boer, B. 1997. Fusicoccin-a key to multiple 14-3-3 locks? Trends Plant Sci. 2: 60-66.

De Feyter, R., Y. Yang, and D.W. Gabriel. 1993. Gene-for-gene interactions between cotton $R$ genes and Xanthomonas campestris pv. malvacearum avr genes. Mol. Plant-Microbe Interact. 6: 225-237.

De Laat, A.M.M. and J.C. Van Loon. 1982. Regulation of ethylene biosynthesis in virus-infected tobacco leaves II: Time course of levels of intermediates and in vivo conversion rates. Plant Physiol. 69: 240-245.

De Wit, P.J.G.M. 1995. Fungal avirulence gene and plant resistance genes: Unravelling the molecular basis of gene-forgene interactions. In $A d v$. Bot. Res. (J.H. Andrews and I.C. Tommerup, eds.) 21: pp. 147-185. Academic Press, London.

Delaney, T.P. 1997. Genetic dissection of acquired resistance to disease. Plant Physiol. 113: 5-12.

Delaney, T., S. Uknes, B. Vernooij, L. Friedrich, K. Weymann, D. Negrotto, T. Gaffney, M. Gut-Rella, H. Kessmann, E. Ward, and J. Ryals. 1994. A central role of salicylic acid in plant disease resistance. Science 266: 1247-1250.

Delaney, T.P., L. Friedrich, and J.A. Ryals. 1995. Arabidopsis signal transduction mutatnt defective in chemically and biologically induced disease resistance. Proc. Natl. Acad. Sci. 92: 6602-6606.

Dempsey, D.A., M.S. Pathirana, K.K. Wobbe, and D.F. Klessig. 1997. Identification of an Arabidopsis locus required for resistance to turnip crinkle virus. Plant $J$. 11: 301-311.

Desikan, R., J.T. Hancock, M.J. Coffey, and S.J. Neill. 1996. Generation of active oxygen in elicited cells of Arabidopsis thaliana is mediated by a NADPH oxidase-like enzyme. FEBS Lett. 382: 213-217.

Després, C., R. Subramaniam, D.P.R. Matton, and N. Brisson. 1995. The activation of the potato PR-10a gene requires the phosphorylation of the nuclear factor PBF-1. Plant Cell 7: 589-598.

Dietrich, A., J.E. Mayer, and K. Hahlbrock. 1990. Fungal elicitor triggers rapid, transient, and specific protein phosphorylation in parsley cell suspension cultures. I. Biol. Chem. 265: 6360-6368.

Dietrich, R.A., T.P. Delaney, S.J. Uknes, E.J. Ward, J.A. Ryals, and J.L. Dangl. 1994. Arabidopsis mutants simulating disease resistance response. Cell 77: 565-578.

Dietrich, R.A., M.H. Richberg, R. Schmidt, C. Dean, and J.L. Dangl. 1997. A novel zinc finger protein is encoded by the Arabidopsis $L S D 1$ gene and functions as a negative regulator of plant cell death. Cell 88: 685-694.

Dixon, M.S., D.A. Jones, J.S. Keddie, C.M. Thomas, K. Harrison, and J.D.G. Jones. 1996. The tomato $C f-2$ disease resistance locus comprises two functional genes encoding leucine-rich repeat proteins. Cell 84: 451-459.

Doares, S.H., J. Narvaez-Vasquez, A. Conconi and C.A. Ryan. 1995a. Salicylic acid inhibits synthesis of proteinase inhibitors in tomato leaves induced by systemin and jasmonic acid. Plant Physiol. 108: 1741-1746.

Doares, S.H., T. Syrovets, E.W. Weiler, and C.A. Ryan. 1995b. Oligogalacturonides and chitosan activate plant defensive genes through the octadecanoid pathway. Proc. Natl. Acad. Sci. 92: 4095-4098.

Doke, N. 1983a. Generation of superoxide anion by potato tuber protoplasts during the hypersensitive response to hyphal wall components of Phytophthora infestans and specific inhibition of the reaction by suppressors of hypersensitivity. Physiol. Plant Pathol. 23: 359-367.

. 1983b. Involvement of superoxide anion generation in the hypersensitive response of potato tuber tissues to infection with an incompatible race of Phytophthora infestans and to the hyphal wall components. Physiol. Plant Pathol. 23: 345-357.

Doke, N. and Y. Ohashi. 1988. Involvement of an $\mathrm{O}_{2}{ }^{-}$generating system in the induction of necrotic lesions on tobacco leaves infected with tobacco mosaic virus. Physiol. Mol. Plant Pathol. 32: 163-175.

Doke, N., Y. Miura, L.M. Sanchez, H.-J. Park, T. Toritake, H. Yoshioka, and K. Kawakita. 1996. The oxidative burst protects plants against pathogen attack: Mechanism and role as an emergency signal for plant bio-defense-a review. Gene 179: 45-51.

Dröge-Laser, W., A. Kaiser, W.P. Lindsay, B.A. Halkier, G.J. Loake, P. Doerner, R.A. Dixon, and C. Lamb. 1997. Rapid stimulation of a soybean protein-serine kinase which phosphorylates a novel bZIP DNA-binding protein, G/HBF-1, during the induction of early transcription-dependent defenses. $E M B O$ I. 16: 726-738.

$\mathrm{Du}, \mathrm{H}$. and D.F. Klessig. 1997. Identification of a soluble, high affinity salicylic acid-binding protein in tobacco. Plant Physiol. 113: 1319-1327.

Dunigan, D.D. and C. Madlener. 1995. Serine/threonine protein phosphatase is required for tobacco mosaic virus-mediated programmed cell death. Virology 207: 460-466.

Durner, J. and D.F. Klessig. 1995. Inhibition of ascorbate peroxidase by salicylic acid and 2,6,-dichloroisonicotinic acid, two inducers of plant defense responses. Proc. Natl. Acad. Sci. 92: 11312-11316.

- 1996. Salicylic acid is a modulator of tobacco and mammalian catalases. J. Biol. Chem. 271: 28492-28501.

Durner, J., J. Shah and D.F. Klessig. 1997. Salicylic acid and disease resistance in plants. Trends Plant Sci. 2: 266-274.

Dwyer, S.C., L. Legendre, P.S. Low, and T.L. Leto. 1995. Plant and human neutrophil oxidative burst complexes contain immunologically related proteins. Biochim. Biophys. Acta 1289: 231-237.

Ebel, I., A.A. Bhagwat, E.G. Cosio, M. Feger, U. Kissel, A. Mithîfer, and T. Waldmüller. 1995. Elicitor-binding proteins and signal transduction in the activation of a phytoalexin defense response. Can. J. Bot. 73(suppl. 1): S506-510.

Ecker, J.R. 1995. The ethylene signal transduction pathway in plants. Science 268: 667-675.

Ellis, J.G., D.J. Llewellyn, J.C. Walker, E.S. Dennis, and W.J. Peacock. 1987. The ocs element: a 16 base pair palindrome essential for activity of the octopine synthase enhancer. EMBO I. 6: 3203-3208.

Ellis, J.G., J.G. Tokuhisa, D.J. Llewellyn, D.J. Bouchez, K. Singh, E.S. Dennis, and W.J. Peacock. 1993. Does the ocs-element occur as a functional component of the promoters of plant genes? Plant J. 4: 433-443.

Enyedi, A.J., N. Yalpani, P. Silverman, and I. Raskin. 1992. Signal molecules in systemic plant resistance to pathogens and pests. Cell 70: 879-886.

Eyal, Y., Y. Meller, S. Lev-Yadun, and R. Fluhr. 1993. A basictype PR-1 promoter directs ethylene responsiveness, vascular and abscission zone-specific expression. Plant J. 4: 225234.

Fang, K.S.F., M. Vitale, P. Fehlner, and T.P. King. 1988. cDNA cloning and primary structure of a white-face hornet venom allergen, antigen 5. Proc. Nat1. Acad. Sci. 85: 895-899.

Farmer, E.E and C.A. Ryan. 1992. Octadecanoid precursors of jasmonic acid activate the synthesis of wound-inducible proteinase inhibitors. Plant Cell 4: 129-134.

Farmer, E.E., D. Caldelari, G. Pearce, M.K. Walker-Simmons, and C.A. Ryan. 1994. Diethyldithiocarbamic acid inhibits the octadecanoid signaling pathway for the wound induction of proteinase inhibitors in tomato leaves. Plant Physiol. 
106: $337-342$.

Fauth, M., A. Merten, M.G. Hahn, W. Jeblick, and H. Kauss. 1996. Competence for elicitation of $\mathrm{H}_{2} \mathrm{O}_{2}$ in hypocotyls of cucumber is induced by breaching the cuticle and is enhanced by salicylic acid. Plant Physiol. 110: 347-354.

Fehlbaum, P., P. Bulet, L. Michaut, M. Lageux, W.F. Broekaert, C. Hétru, and J.A. Hoffmann. 1994. Insect immunity: Septic injury of Drosophila induces the synthesis of a potent antifungal peptide with sequence homology to plant antifungal peptides. I. Biol. Chem. 269: 33159-33163.

Felix, G., D.G. Grosskopf, M. Regenass, and T. Boller. 1991. Rapid changes of protein phosphorylation are involved in transduction of the elicitor signal in plant cells. Proc. Natl. Acad. Sci. 88: 8831-8834.

Felix, G., M. Regenass, P. Spanu, and T. Boller. 1994. The protein phosphatase inhibitor calyculin A mimics elicitor action in plant cells and induces rapid hyperphosphorylation of specific proteins as revealed by pulse labeling with $\left[{ }^{33} \mathrm{P}\right]$ phosphate. Proc. Natl. Acad. Sci. 91: 952-956.

Feuillet, C., G. Schachermayr, and B. Keller. 1997. Molecular cloning of a new receptor-like kinase gene encoded at the Lr10 disease resistance locus of wheat. Plant J. 11: 45-52.

Feys, B.J.F., C.E. Benedetti, C.N. Penfold, and J.G. Turner. 1994. Arabidopsis mutants selected for resistance to the phytotoxin coronatine are male sterile, insensitive to methyl jasmonate, and resistant to a bacterial pathogen. Plant Cell 6: 751-759.

Flor, H.H. 1971. Current status of gene-for-gene concept. Annu. Rev. Phytopathol. 9: 275-296.

Friedrich, L., K. Lawton, S. Dincher, A. Winter, T. Staub, S. Uknes, H. Kessmann, and J. Ryals. 1996. Benzothiadiazole induces systemic acquired resistane in tobacco. Plant $J$. 10: $61-70$.

Gabriel, D.W. and B.G. Rolfe. 1990. Working models of specific recognition in plant-microbe interactions. Annu. Rev. Phytopathol. 28: 365-391.

Gabriel, D.W., Q. Yuan, Y. Yang, and P.K. Chakrabarty. 1996. Role of nuclear localization signal sequences in three disease phenotypes determined by the Xanthomonas avr/pth gene family. In Biology of plant-microbe interactions (ed. G. Stacey, B. Mullin, and P.M. Gresshoff|, pp. 197-202. International Society of Molecular Plant-Microbe Interactions, St. Paul, MN.

Gaffney, T., L. Friedrich, B. Vernooij, D. Negrotto, G. Nye, S. Uknes, E. Ward, H. Kessmann, and J. Ryals. 1993. Requirement of salicylic acid for the induction of systemic acquired resistance. Science 261:754-756.

Glazebrook, J., E.E. Rogers, and F.M. Ausubel. 1996. Isolation of Arabidopsis mutants with enhanced disease susceptibility by direct screening. Genetics 143: 973-982.

Glazebrook, J., M. Zook, F. Mert, I. Kagan, E.E. Rogers, I.R. Crute, E.B. Houlb, R. Hammerschmidt, and F.M. Ausubel. 1997. Phytoalexin-deficient mutants of Arabidopsis reveal that $P A D 4$ encodes a regulatory factor and that four $P A D$ genes contribute to downy mildew resistance. Genetics 146: $381-392$

Goldsbrough, A.P., H. Albrecht, R. Stratford. 1993. Salicylic acid-inducible binding of a tobacco nucelar protein to a $10 \mathrm{bp}$ sequence which is highly conserved amongst stress-inducible genes. Plant I. 3: 563-571.

Goodman, R.N. and A. Novacky. 1994. The hypersensitive reaction in plants to pathogens. A resistance phenomenon. American Phytopathological Society Press, St. Paul, MN.

Gopalan, S., D.W. Bauer, J.R. Alfano, A.O. Loniello, S.Y. He, and A. Collmer. 1996. Expression of the Pseudomonas syringae avirulence protein AvrB in plant cells alleviates its depen- dence on the hypersensitive response and pathogenicity (Hrp) secretion system in eliciting genotype-specific hypersensitive cell death. Plant Cell 8: 1095-1105.

Gorina, S. and N.P. Pavletich. 1996. Structure of the p53 tumor suppressor bound to the ankyrin and SH3 domains of 53BP2. Science 274: 1001-1005.

Görlach, J., S. Volrath, G. Knauf-Beiter, G. Hengy, U. Beckhove, K.-H. Kogel, M. Oostendorp, T. Staub, E. Ward, H. Kessmann, and J. Ryals. 1996. Benzothiadiazole, a novel class of inducers of systemic acquired resistance, activates gene expression and disease resistance in wheat. Plant Cell 8: 629643.

Grant, M.R., L. Godiard, E. Straube, T. Ashfield, J. Lewald, A. Sattler, R.W. Innes, and J.L. Dangl. 1995. Structure of the Arabidopsis RPM1 gene enabling dual specific disease resistance. Science 269: 843-846.

Green, R. and R. Fluhr. 1995. UV-B-induced PR-1 accumulation is mediated by active oxygen species. Plant Cell 7: 203-212.

Greenberg, J.T. 1996. Programmed cell death: A way of life for plants. Proc. Nat1. Acad. Sci. 93: 12094-12097.

Greenberg, J.T., A. Guo, D.F. Klessig, and F.M. Ausubel. 1994. Programmed cell death in plants: A pathogen-triggered response activated coordinately with multiple defense functions. Cell 77: 551-563.

Groom, Q.J., M.A. Torres, A.P. Fordham-Skelton, K.E. Hammond-Kosack, N.J. Robinson, and J.D.G. Jones. 1996. $R b \circ h A$, a rice homologue of the mammalian gp91phox respiratory burst oxidase gene. Plant $J$. 10: 515-522.

Grotewold, E., B.J. Drummond, B. Bowen, and T. Peterson. 1994. The $m y b$-homologous $P$ gene controls phlobaphene pigmentation in maize floral organs by directly activating a flavonoid biosynthetic gene subset. Cell 76: 543-553.

Gundlach, H., M.J. Müller, T.M. Kutchan, and M.H. Zenk. 1992. Jasmonic acid is a signal transducer in elicitor-induced plant cell cultures. Proc. Natl. Acad. Sci. 89: 2389-2393.

Guzman, P. and J.R. Ecker. 1990. Exploiting the triple response of Arabidopsis to identify ethylene-related mutants. Plant Cell 2: 513-523.

Hahlbrock, K., D. Scheel, E. Logemenn, T. Nürnberger, M. Papniske, S. Reinold, W.R. Sacks, and E. Schmelzer. 1995. Oligopeptide elicited defense gene activation in cultured parsley cells. Proc. Natl. Acad. Sci. 92: 4150-4157.

Hahn, M.G. 1996. Microbial elicitors and their receptors in plants. Annu. Rev. Phytopathol. 34: 387-412.

Hammond-Kosack, K.E. and J.D.G. Jones. 1996. Resistance gene-dependent plant defense responses. Plant Cell 8:17731791.

Hammond-Kosack, K.E., P. Silverman, I. Raskin, and J.D.G. Jones. 1996. Race-specific elicitors of Cladosporium fulvum induce changes in cell morphology, and ethylene and salicylic acid synthesis, in tomato cells carrying the corresponding Cf-disease resistance gene. Plant Physiol. 110: 13811394.

Herbers, K., J. Conrads-Strauch, and U. Bonas. 1992. Race-specificity of plant resistance to bacterial spot disease determined by repetitive motifs in a bacterial avirulence protein. Nature 356: 172-174.

Herbers, K., P. Meuwly, W.B. Frommer, J.-P. Métraux, and U. Sonnewald. 1996. Systemic acquired resistance mediated by the ectopic expression of invertase: Possible hexose sensing in the secretory pathway. Plant Cell 8: 793-803.

Jabs, T., R.A. Dietrich, and J.L. Dangl. 1996. Initiation of runaway cell death in an Arabidopsis mutant by extracellular superoxide. Science 273: 1853-1856.

Jabs, T., M. Tschõpe, C. Colling, K. Hahlbrock, and D. Scheel. 1997. Elicitor-stimulated ion fluxes and $\mathrm{O}_{2}{ }^{-}$from the oxi- 
dative burst are essential components in triggering defense gene activation and phytoalexin synthesis in parsley. Proc. Nat1. Acad. Sci. 94: 4800-4805.

Jia, Y.L., Y.T. Loh, J.M. Zhou, and G.B. Martin. 1997. Alleles of Pto and Fen occur in bacterial speck-susceptible and fenithion-insensitive tomato cultivars and encode active protein kinases. Plant Cell 9: 61-73.

Jonak, C., S. Kiegerl, W. Ligterink, P.J. Barker, N.S. Huskisson, and H. Hirt. 1996. Stress signaling in plants: A MAP kinase pathway is activated by cold and drought. Proc. Natl. Acad. Sci. 93: 11274-11279.

Jones, J.D.G. 1996. Plant disease resistance genes: Structure, function and evolution. Curr. Opin. Biotech. 7: 155-160.

Jones, D.A., C.M. Thomas, K.E. Hammond-Kosack, P.J. BalintKurti, and J.D.G. Jones. 1994. Isolation of the tomato Cf-9 gene for resistance to Cladosporium fulvum by transposon tagging. Science 266: 789-793.

Jufuku, K.D., B.G.W. den Boer, M. van Montagu, and J.K. Okamuro. 1994. Control of Arabidopsis flower and seed development by the homeotic gene APETALA2. Plant Cell 6: $1211-1225$

Jupin, I. and N.-H. Chua. 1996. Activation of the CaMV as-1 cis-element by salicylic acid: Differential DNA-binding of a factor related to TGA1a. EMBO I. 15: 5679-5689.

Kanazin, V., L.F. Marek, and R.C. Shoemaker. 1996. Resistance gene analogs are conserved and clustered in soybean. Proc. Nat1. Acad. Sci. 93: 11750-11755.

Katagiri, F., E. Lam, and N.-H. Chua. 1989. Two tobacco DNAbinding proteins with homology to the nuclear factor CREB Nature 340: 727-730.

Kauss, H., E. Theisinger-Hinkel, R. Mindermann, and U. Conrath. 1992. Dichloroisonicotinic and salicylic acid, in. ducers of systemic acquired resistance, enhance fungal elicitor responses in parsley cells. Plant T. 2: 655-660.

Kearney, B. and B.J. Staskawicz. 1990. Widespread distribution and fitness contribution of Xanthomonas campestris avirulence gene avrBs2. Nature 346: 385-386.

Kim, S.-R., Y. Kim, and G. An. 1993. Identification of methyl jasmonate and salicylic acid response elements from the nopaline synthase (nos) promoter. Plant Physiol. 103: 97-103.

Klessig, D.F., J. Durner, Z. Chen, M. Anderson, U. Conrath, H. Du, A. Guo, Y. Liu, J. Shah, H. Silva, H. Takahashi, and Y. Yang. 1996. Studies of the salicylic acid signal transduction pathway. In Biology of plant-microbe interactions (ed. G. Stacey, B. Mullin, and P.M. Gresshoff), pp. 33-38. International Society of Molecular Plant-Microbe Interactions, St. Paul, MN.

Kobe, B. and J. Deisenhofer. 1995. Proteins with leucine-rich repeats. Curr. Opin. Struct. Biol. 5: 409-416.

Korfhage, U., G.F. Trezzini, I. Meier, K. Hahlbrock, and I.E. Somssich. 1994. Plant homeodomain protein involved in transcriptional regulation of a pathogen defense-related gene. Plant Cell 6: 695-708.

Krappmann, D., F.G. Wulczyn, and C. Scheidereit. 1996. Different mechanisms control signal-induced degradation and basal turnover of the NF-кB inhibitor $\mathrm{I} \mathrm{B}$ in vivo. EMBO $J$. 15: 6716-1726.

Kuchitsu, K., M. Kikuyama, and N. Shibuya. 1993. N-acetylchitooligosaccharides, biotic elicitors for phytoalexin production, induce transient membrane depolarization in suspension-cultured rice cells. Protoplasma 174: 79-81.

Lam, E., P.N. Benfy, P.M. Gilmartin, F. Rong-Xiang, and N.-H. Chua. 1989. Site-specific mutations alter in vitro factor binding and change promoter expression pattern in transgenic plants. Proc. Natl. Acad. Sci. 86: 7890-7894.

Lawrence, G.J., E.J. Finnegan, M.A. Ayliffe, and J.G. Ellis. 1995.
The $L 6$ gene for flax rust resistance is related to the Arabidopsis bacterial resistance gene RPS2 and the tobacco viral resistance gene N. Plant Cell 7: 1195-1206.

Lawton, K.A., S.L. Potter, S. Uknes, and J. Ryals. 1994. Acquired resistance signal transduction in Arabidopsis is ethylene independent. Plant Cell 6: 581-588.

Lawton, K., K. Weymann, L. Friedrich, B. Vernooij, S. Uknes, and J. Ryals. 1995. Systemic acquired resistance in Arabidopsis requires salicylic acid but not ethylene. Mol. PlantMicrobe Interact. 8: 863-870.

Lawton, K., L. Friedrich, M. Hunt, K. Weymann, T. Staub, H. Kessmann, and J. Ryals. 1996. Benzothiadiazole induces disease resistance in Arabidopsis by activation of the systemic acquired resistance signal transduction pathway. Plant $J$. 10: $71-82$.

Leach, J.E. and F.F. White. 1996. Bacterial avirulence genes. Annu. Rev. Phytopathol. 34: 153-179.

Legendre, L., P.F. Heinstein, and P.S. Low. 1992. Evidence for participation of GTP-binding proteins in elicitation of the rapid oxidative burst in cultured soybean cells. I. Biol. Chem. 267: 20140-20147.

Leister, D., A. Ballvora, F. Salamini, and C. Gebhardt. 1996. A PCR-based approach for isolating pathogen resistance genes from potato with potential for wide application in plants. Nature Genet. 14: 421-429.

Leister, R.T., F.M. Ausubel, and F. Katagiri. 1996. Molecular recognition of pathogen attack occurs inside of plant cells in plant disease resistance specified by the Arabidopsis gene RPS2 and RPM1. Proc. Nat1. Acad. Sci. 93: 15497-15502.

Lemaitre, B., E. Nicolas, L. Michaut, J.-M. Reichhart, and J.A. Hoffmann. 1996. The dorsoventral regulatory gene cassette spätzle/Toll/cactus controls the potent antifungal response in Drosophila adults. Cell 86: 973-983.

Léon, J., M.A. Lawton, and I. Raskin. 1995. Hydrogen peroxide stimulates salicylic acid biosynthesis in tobacco. Plant Physiol. 108: 1673-1678.

Levine, A., R. Tenhaken, R. Dixon, and C. Lamb. 1994. $\mathrm{H}_{2} \mathrm{O}_{2}$ from the oxidative burst orchestrates the plant hypersensitive disease resistance response. Cell 79: 583-595.

Low, P.S. and J.R. Merida. 1996. The oxidative burst in plant defense: Function and signal transduction. Physiol. Plant. 96: 533-542.

Mackintosh, C., G.D. Lyon, and R.W. Mackintosh. 1994. Protein phosphatase inhibitors activate anti-fungal defense responses of soybean cotyledons and cell cultures. Plant $I$. 5: 137-147.

Malamy, J., J.P. Carr, D.F. Klessig, and I. Raskin. 1990. Salicylic acid: A likely endogenous signal in the resistance response of tobacco to viral infection. Science 250: 1002-1004.

Malamy, J., P. Sánchez-Casas, J. Hennig, A. Guo, and D.F. Klessig. 1996. Dissection of the salicylic acid signaling pathway in tobacco. Mol. Plant-Microbe Interact. 9: 474-482.

Martin, G.B., S.H. Brommonschenkel, J. Chunwongse, A. Frary, M.W. Ganal, R. Spivey, T. Wu, E.D. Earle, and S.D. Tanksley. 1993. Map-based cloning of a protein kinase gene conferring disease resistance in tomato. Science 262: 1432-1436.

Mathieu, Y., A. Kurkjian, H. Xia, J. Guern, M. Spiro, M. O'Neill, P. Albersheim, and A. Darvill. 1991. Membrane responses induced by oligogalacturonides in suspension-cultured tobacco cells. Plant I. 1: 333-343.

Mauch, F., L.A. Hadwiger, and T. Boller. 1984. Ethylene: Symptom not signal for the induction of chitinase and $\beta-1,3$-glucanase in pea pods by pathogens and elcitors. Plant Physiol. 76: 607-611.

Mauch-Mani, B. and A.J. Slusarenko. 1996. Production of sali- 
cylic acid precursors is a major function of phenylalanine ammonia-lyase in the resistance of Arabidopsis to Pernospora parasitica. Plant Cell 8: 203-212.

May, M.J., K.E. Hammond-Kosack, and J.D.G. Jones. 1996. Involvement of reactive oxygen species, glutathione metabolism, and lipid peroxidation in the $C f$-gene-dependent defense response of tomato cotyledons induced by race-specific elicitors of Cladosporium fulvum. Plant Physiol. 110: 1367-1379.

McGrul, B., G. Pearce, M. Orizco-Cardensa, and C.A. Ryan. 1992. Structure, expression and antisense inhibition of the systemin precursor gene. Science 255: 1570-1573.

Meier, I., K. Hahlbrock, and I.E. Somssich. 1991. Elicitor-inducible and constitutive in vivo DNA footprints indicate novel cis-acting elements in the promoter of a parsley gene encoding pathogenesis-related protein 1. Plant Cell 3:309-315.

Menkens, A.E., U. Schindler, and A.R. Cashmore. 1995. The G-box: A ubiquitous regulatory DNA element in plants bound by the GBF family of bZIP proteins. Trends Biochem. Sci. 20: 506-510.

Métraux, J.-P., H. Signer, J. Ryals, E. Ward, M. Wyss-Benz, J. Gaudin, K. Raschdorf, E. Schmid, W. Blum, and B. Inverardi. 1990. Increase in salicylic acid at the onset of systemic acquired resistance in cucumber. Science 250: 1004-1006.

Miao, Z.H., X.J. Liu, and E. Lam. 1994. TGA3 is a distinct member of the TGA family of bZIP transcription factors in Arabidopsis thaliana. Plant Mol. Biol. 25: 1-11.

Midland, S.L., N.T. Keen, J.J. Sims, M.M. Midland, M.M. Stayton, V. Burton, M.J. Smith, E.P. Mazzola, and J. Clardy. 1993. The structures of syringolides 1 and 2, novel C-glycosidic elicitors from Pseudomonas syringae pv. tomato. I. Org. Chem. 58: 2940-2945.

Mindrinos, M., F. Katagiri, G.-L. Yu, and F.M. Ausubel. 1994. The Arabidopsis thaliana disease resistance gene RPS2 encodes a protein containing a nucleotide-binding site and leucine-rich repeats. Cell 78: 1089-1099.

Mittler, R., V. Shulaev, and E. Lam. 1995. Coordinated activation of programmed cell death and defense mechanisms in transgenic tobacco plants expressing a bacterial proton pump. Plant Cell 7: 29-42.

Mizoguchi, T., K. Irie, T. Hirayama, N. Hayashida, K. Yamaguchi-Shinozaki, K. Matsumota, and K. Shinozaki. 1996. A gene encoding a mitogen-activated protein kinase kinase kinase is induced simultaneously with genes for a mitogenactivated protein kinase and an $\mathrm{S} 6$ ribosomal protein kinase by touch, cold, and water stress in Arabidopsis thaliana. Proc. Natl. Acad. Sci. 93: 765-769.

Mur, L.A.J., G. Naylor, S.A.J. Warner, J.M. Sugars, R.F. White and J. Draper. 1996. Salicylic acid potentiates defence gene expression in tissue exhibiting acquired resistance to pathogen attack. Plant I. 9: 559-571.

Murphy, E.V., Y. Zhang, W. Zhu, and J. Biggs. 1995. The human glioma pathogenesis-related protein is structurally related to plant pathogenesis-related proteins and its gene is expressed specifically in brain tumors. Gene 159: 131-135.

Neuenschwander, U., B. Vernooij, L. Friedrich, S. Uknes, H. Kessmann, and J. Ryals. 1995. Is hydrogen peroxide a second messenger of salicylic acid in systemic acquired resistance? Plant T. 8: 227-234.

Neuhaus, G., G. Neuhaus-Uri, F. Katagiri, K. Seipel, and N.-H. Chua. 1994. Tissue-specific expression of as-1 in transgenic tobacco. Plant Cell 6: 827-834.

Nürnberger, T., D. Nennstiel, T. Jabs, W.R. Sacks, K. Hahlbrock, and D. Scheel. 1994. High affinity binding of a fungal oligopeptide elicitor to parsley plasma membranes triggers multiple defense responses. Cell 78: 449-460.

- 1995. Covalent cross-linking of the Phytophthora mega- sperma oligopeptide elicitor to its receptor in parsley membranes. Proc. Nat1. Acad. Sci. 92: 2338-2342.

Ohme-Takagi, M. and H. Shinshi. 1995. Ethylene-inducible DNA binding proteins that interact with an ethylene-responsive element. Plant Cell 7: 173-182.

Ori, N., Y. Eshed, I. Paran, G. Presting, D. Aviv, S. Tanksley, D. Zamir, and R. Fluhr. 1997. The I2C family from the wilt disease resistance locus $I 2$ belongs to the nucleotide binding, leucine-rich repeat superfamily of plant disease resistance genes. Plant Cell 9: 521-532.

Parker, J.E., E.B. Houlb, L.M. Frost, A. Falk, N.D. Gunn, and M.J. Daniels. 1996. Characterization of eds1, a mutation in Arabidopsis suppressing resistance to Pernospora parasitica specified by several differenet RPP genes. Plant Cell 8: 20332046.

Pastuglia, M., D. Roby, C. Dumas, and J.M. Cock. 1997. Rapid induction by wounding and bacterial infection of an $S$ gene family receptor-like kinase gene in Brassica oleracea. Plant Cell 9: 49-60.

Pearce, G., D. Strydom, S. Johnson, and C. Ryan. 1991. A polypeptide from tomato leaves induces wound-inducible proteinase inhibitor proteins. Science 253: 895-898.

Peña-Cortés, H., T. Albrecht, S. Prat, E.W. Water, and L. Willmitzer. 1993. Aspirin prevents wound-induced gene expression in tomato leaves by blocking jasmonic acid biosynthesis. Planta 191: 123-128.

Peng, M. and J. Kuc. 1992. Peroxidase-generated hydrogen peroxide as a source of antifungal activity in vitro and on tobacco leaf discs. Phytopathology 82: 696-699.

Penninckx, I.A.M.A., K. Eggermont, F.R.G. Terras, B.P.H.J. Thomas, G.W.D. Samblanx, A. Buchala, J.-P. Métraux, J.M. Manners, and W.F. Broekaert. 1996. Pahthogen-induced systemic activation of a plant defensin gene in Arabidopsis follows a salicylic acid-independent pathway. Plant Cell 8: 2309-2323.

Pieterse, C.M.J., S.C.M. van Wees, E. Hoffland, J.A. van Pelt, and L.C. van Loon. 1996. Systemic resistance in Arabidopsis induced by biocontrol bacteria is independent of salicylic acid accumulation and pathogenesis-related gene expression. Plant Cell 8: 1225-1237.

Popham, P., S. Pike, and A. Novacky. 1995. The effect of harpin from Erwinia amylovora on the plasmalemma of suspesioncultured tobacco cells. Physiol. Mol. Plant Pathol. 47: 39-50.

Price, A.H., A. Taylor, S.J. Ripley, A. Griffiths, A.J. Trewavas, and M.R. Knight. 1994. Oxidative signals in tobacco increase cytosolic calcium. Plant Cell 6: 1301-1310.

Qin, X.F., L. Holuigue, D.M. Horvath, and N.-H. Chua. 1994. Immediate early transcription activation by salicylic acid via the cauliflower mosaic virus as-1 element. Plant Cell 6: 863874.

Rasmussen, J.B., R. Hammerschmidt, and M.N. Zook. 1991. Systemic induction of salicylic acid accumulation in cucumber after inoculation with Pseudomonas syringae pv. syringae. Plant Physiol. 97: 1342-1347.

Raventós, D., A.B. Jensen, M.-B. Rask, J.M. Casacuberta, J. Mundy, and B. San Segundo. 1995. A 20 bp cis-acting element is both necessary and sufficient to mediate elicitor response of a maize Prms gene. Plant J. 7: 147-155.

Raz, V. and R. Fluhr. 1992. Calcium requirement for ethylenedependent responses. Plant Cell 4: 1123-1130.

Reinbothe, S., B. Mollenhauer, and C. Reinbothe. 1994a. JIPs and RIPs: The regulation of plant gene expression by jasmonates in response to environmental cues and pathogens. Plant Cell 6: 1197-1209.

Reinbothe, S., C. Reinbothe, J. Lehmann, W. Becker, K. Apel, and B. Parthier. 1994b. JIP60, a methyl jasmonate-induced 
ribosome-inactivating protein involved in plant stress reactions. Proc. Nat1. Acad. Sci. 91: 7012-7016.

Rieping, M., M. Frits, S. Prat, and C. Gatz. 1994. A dominant negative mutant of PG13 supresses transcription from a cauliflower mosaic virus $35 \mathrm{~S}$ truncated promoter in transgenic tobacco plants. Plant Cell 6: 1087-1098.

Rohe, M., A. Gierlich, H. Hermann, M. Hahn, B. Schmidt, S. Rosahl, and W. Knogge. 1995. The race-specific elicitor, NIP1, from the barley pathogen, Rhynchosporium secalis, determines avirulence on host plants of the Rrs 1 resistance genotype. EMBO /. 14: 4168-4177.

Roine, E., W. Wei, J. Yuan, E.-L., Nurmiaho-Lassila, N. Kalkkinen, M. Romantschuk, and S.Y. He. 1997. Hrp pilus: An hrp-dependent bacterial surface appendage produced by Pseudomonas syringae pv. tomato DC3000. Proc. Natl. Acad. Sci. 94: 3459-3464.

Rushton, P.J., J.T. Torres, M. Parniske, P. Wernert, K. Hahlbrock, and I.E. Somssich. 1996. Interaction of elicitor-induced DNA-binding proteins with elicitor response elements in the promoters of parsley PR-1 genes. EMBO $\mathrm{J}$. 15: $5690-5700$.

Ryals, J.A., U.H. Neuenschwander, M.G. Willits, A. Molina, H.-Y. Steiner, and M.D. Hunt. 1996. Systemic acquired resistance. Plant Cell 8: 1809-1819.

Ryals. J., K. Weymann, K. Lawton, L. Friedrich, D. Ellis, H.-Y. Steiner, J. Johnson, T.P. Delaney, T. Jesse, P. Vos, and S. Uknes. 1997. The Arabidopsis thaliana NIM1 protein shows homology to the mammalian transcription factor inhibitor IkB. Plant Cell 9: 425-439.

Sablowski, R.W., E. Moyano, F.A. Culianez-Macia, W. Schuch, C. Martin, and M.A. Bevan. 1994. Flower-specific Myb protein activates transcription of phenylpropanoid biosynthetic genes. $E M B O$ I. 13: 128-137.

Salmeron, J.M., G.E.D. Oldroyd, C.M.T. Rommens, S.R. Scofield, H.-S. Kim, D.T. Lavelle, D. Dahlbeck, and B.J. Staskawicz. 1996. Tomato Prf is a member of the leucine-rich-repeat class of plant disease resistance genes and lies embedded within the Pto kinase gene cluster. Cell 86: 123-133.

Sano, H., S. Seo, E. Orudgev, S. Youssefian, K. Ishizuka, and Y. Ohashi. 1994. Expression of the gene for a small GTP binding protein in transgenic tobacco elevates endogenous cytokinin levels, abnormally induces salicylic acid in response to wounding, and increases resistance to tobacco mosaic virus infection. Proc. Nat1. Acad. Sci. 91: 10556-10560.

Scofield, S.R., C.M. Tobias, J.P. Rathjen, J.H. Chang, D.T. Lavelle, R.W. Michelmore, and B.J. Staskawicz. 1996. Molecular basis of gene-for-gene specificity in bacterial speck disease of tomato. Science 274: 2063-2065.

Sen, C.K. and L. Packer. 1996. Antioxidant and redox regulation of gene transcription. FASEB J. 10: 709-720.

Seo, S., M. Okamoto, H. Seto, K. Ishizuka, H. Sano, and Y. Ohashi. 1995. Tobacco MAP kinase: A possible mediator in wound signal transduction pathways. Science 270: 19881992.

Shah, J. and D.F. Klessig. 1996. Identification of a salicylic acidresponsive element in the promoter of the tobacco pathogenesis-related $\beta-1,3$-glucanase gene, PR-2d. Plant $I$. 10: 1089-1101.

Shah, J., F. Tsui, and D.F. Klessig. 1997. Characterization of a salicylic acid-insensitive mutant (sail) of Arabidopsis thaliana, identified in a selective screen utilizing the SAinducible expression of the tms2 gene. Mol. Plant-Microbe Interact. 10: 69-78.

Shirasu, K., H. Nakajima, V.K. Rajasekhar, R.A. Dixon, and C. Lamb. 1997. Salicylic acid potentiates an agonist-dependent gain control that amplifies pathogen signals in the activation of defense mechanisms. Plant Cell 9: 261-270.

Shulaev, V., H. León, and I. Raskin. 1995. Is salicylic acid a translocated signal of systemic acquired resistance in plants? Plant Cell 7: 1691-1701.

Shulaev, V., P. Silverman, and I. Raskin. 1997. Airborne signaling by methyl salicylate in plant pathogen resistance. Nature 385: 718-721.

Song, W.-Y., G.-L. Wang, L.-L. Chen, H.-S. Kim, L.-Y. Pi, T. Holsten, J. Gardner, B. Wang, W.-X. Zhai, L.-H. Zhu, C. Fauquet, and P. Ronald. 1995. A receptor kinase-like protein encoded by the rice disease resistance gene, $\mathrm{Xa21}$. Science 270: 1804-1806.

Stephens, C. and L. Shapiro. 1996. Bacterial pathogenesis: Delivering the payload. Curr. Biol. 6: 927-930.

Subramaniam, R., C. Després, and N. Brisson. 1997. A functional homolog of mammalian protein kinase $C$ participates in the elicitor-induced defense response in potato. Plant Cell 9: 653-664.

Summermatter, K., L. Sticher, and J.-P. Métraux. 1995. Systemic responses in Arabidopsis thaliana infected and challenged with Pseudomonas syringae pv syringae. Plant Physiol. 108: 1379-1385.

Suzuki, K. and H. Shinshi. 1995. Transient activation and tyrosine phosphorylation of a protein kinase in tobacco cells treated with fungal elicitor. Plant Cell 7: 639-647.

Suzuki, K., Y. Fukuda, and H. Shinshi. 1995. Studies on elicitorsignal transduction leading to differential expression of defense genes in cultured tobacco cells. Plant Cell Physiol. 36: 281-289.

Takahashi, H., Z. Chen, H. Du, Y. Liu, and D.F. Klessig. 1997. Development of necrosis and activation of disease resistance in transgenic tobacco plants with severely reduced catalase levels. Plant I. 11: 993-1005.

Tang, X., R.D. Frederick, J. Zhou, D.A. Halterman, Y. Jia, and G.B. Martin. 1996. Initiation of plant disease resistance by physical interaction of AvrPto and the Pto kinase. Science 274: $2060-2063$.

Tenhaken, R., A. Levine, L.F. Brisson, R.A. Dixon, and C. Lamb. 1995. Function of the oxidative burst in hypersensitive disease resistance. Proc. Natl. Acad. Sci. 92: 4158-4163.

Terras, F.R.G., K. Eggermont, V. Kovaleva, N.V. Raikhel, R.W. Osborn, A. Kester, S.B. Rees, S. Torrekens, F. Van Leuven, J. Vanderleyden, B.P.A. Cammue, and W.F. Broekaert. 1995. Small cysteine-rich antifungal proteins from radish (Raphanus sativus L.): Their role in host defense. Plant Cell 7:573-588.

Uknes, S., B. Mauch-Mani, M. Moyer, S. Potter, S. Williams, S. Dincher, D. Chandler, A. Slusarenko, E. Ward, and J. Ryals. 1992. Acquired resistance in Arabidopsis. Plant Cell 4: 645656.

Uknes, S., A.M. Winter, T. Delaney, B. Vernooij, A. Morse, L. Friedrich, G. Nye, S. Potter, E. Ward, and J. Ryals. 1993. Biological induction of systemic acquired resistance in Arabidopsis. Mol. Plant-Microbe Interact. 6: 692-698.

Ulmasov, T., G. Hagen, and T. Guilfoyle. 1994. The ocs element in the soybean $G H 2 / 4$ promoter is activated by both active and inactive auxin and salicylic acid analogues. Plant Mol. Biol. 26: 1055-1064.

Ulmasov, T., A. Ohmiya, G. Hagen, and T. Guilfoyle. 1995. The soybean $\mathrm{GH} 2 / 4$ gene that encodes a glutathione S-transferase has a promoter that is activated by a wide range of chemical agents. Plant Physiol. 108: 919-927.

Umemoto, N., M. Kakitani, A. Iwamatsu, M. Yoshikawa, N. Yamaoka, and I. Ishida. 1997. The structure and function of a soybean $\beta$-glucan-elicitor-binding protein. Proc. Natl. Acad. Sci. 94: 1029-1034.

van den Ackerveken, G., E. Marois, and U. Bonas. 1996. Recog- 
nition of the bacterial avirulence protein AvrBs3 occurs inside the host plant cell. Cell 87: 1307-1316.

van de Zaal, B.J., F.N.J. Droog, F.J. Pieterse, and P.J.J. Hooykaas. 1996. Auxin-sensitive elements from promoters of tobacco GST genes and a consensus as-1-like element differ only in relative strength. Plant Physiol. 110: 79-88.

Van Loon, L.C. 1983. The induction of pathogenesis-related proteins by pathogens and specific chemicals. Neth. I. Plant Pathol. 89: 265-273.

Vera-Estrella, R., B.J. Barkla, V.J. Higgins, and E. Blumwald. 1994a. Plant defense response to fungal pathogens: Activation of host plasma membrane $\mathrm{H}^{+}$-ATPase by elicitor-induced enzyme dephosphorylation. Plant Physiol, 104: 209-215.

- 1994b. Plant defense response to fungal pathogens II: G-protein-mediated changes in host plasma membrane redox reactions. Plant Physiol. 106: 97-102.

Vernooij, B., L. Friedrich, A. Morse, R. Reist, R. Kolditz-Jawhar, E. Ward, S. Uknes, H. Kessmann, and J. Ryals. 1994. Salicylic acid is not the translocated signal responsible for inducing systemic acquired resistance but is required in signal translocation. Plant Cell 6: 959-965.

Vernooij, B., L. Friedrich, P. Ahl-Goy, T. Staub, H. Kessmann, and J. Ryals. 1995. 2,6-Dichloroisonicotinic acid-induced resistance to pathogens does not require the accumulation of salicylic acid. Mol. Plant-Microbe Interact. 8: 228-234.

Vidal, S., I.P. de Leon, J. Denecke, and E.T. Palva. 1997. Salicylic acid and the plant pathogen Erwinia carotovora induce defense genes via antagonistic pathways. Plant $J$. 11: 115-123.

Vogeli, U., F.J. Meins, and T. Boller. 1988. Coordinated regulation of chitinase and $\beta-1,3$-glucanase in bean leaves. Planta 174: 364-372.

Wang, X., P. Zafian, M. Choudhary, and M. Lawton. 1996. The PR5K receptor protein kinase from Arabidopsis thaliana is structurally related to a family of plant defense proteins. Proc. Natl. Acad. Sci. 93: 2598-2602.

Ward, E.R., S.J. Uknes, S.C. Williams, S.S. Dincher, D.L. Wiederhold, D.C. Alexander, P. Ahl-Goy, J.-P. Métraux, and J.A. Ryals. 1991. Coordinate gene activity in response to agents that induce systemic acquired resistance. Plant Cell 3: 1085-1094.

Wevelsiep, L., E. Rupping, and W. Knogge. 1993. Stimulation of barley plasmalemma $\mathrm{H}^{+}$-ATPase by phytotoxic peptides from the fungal pathogen, Rhynchosporium secalis. Plant Physiol. 101: 297-301.

Weymann, K., M. Hunt, S. Uknes, U. Neuenschwander, K. Lawton, H.-Y. Steiner, and J. Ryals. 1995. Suppression and restoration of lesion formation in Arabidopsis lsd mutants. Plant Cell 7: 2013-2022.

Whitham, S., S.P. Dinesh-Kumar, D. Choi, R. Hehl, C. Corr, and B. Baker. 1994. The product of the tobacco mosaic virus resistance gene $N$ : Similarity to Toll and the interleukin-1 receptor. Cell 78: 1101-1115.

Wu, G., B.J. Shortt, E.B. Lawrence, E.B. Levine, K.C. Fitzsimmons, and D.M. Shah. 1995. Disease resistance conferred by expression of a gene encoding $\mathrm{H}_{2} \mathrm{O}_{2}$-generating glucose oxidase in transgenic potato plants. Plant Cell 7: 1357-1368.

Xing, T., V.J. Higgins, and E. Blumwald. 1996. Regulation of plant defense response to fungal pathogens: Two types of protein kinases in the reversible phosphorylation of the host plasma membrane $\mathrm{H}^{+}$-ATPase. Plant Cell 8: 555-564.

1997. Race-specific elicitors of Cladosporium fulvum promote translocation of cytosolic components of NADPH oxidase to the plasma membrane of tomato cells. Plant Cell 9: 249-259.

Xu, Y., P.F.L. Chang, D. Liu, M.L. Narasimhan, K.G. Raghothanma, P.M. Gasegawa, and R.A. Bressan. 1994. Plant de- fense genes are synergistically induced by ethylene and methyl jasmonate. Plant Cell 6: 1077-1085.

Yang, Y. and D.F. Klessig. 1996. Isolation and characterization of a tobacco mosaic virus-inducible myb oncogene homolog from tobacco. Proc. Natl. Acad. Sci. 93: 14972-14977.

Yang, Y. and D.W. Gabriel. 1995a. Xanthomonas avirulence/ pathogenicity gene family encodes functional plant nuclear targeting signals. Mol. Plant-Microbe Interact. 8: 627-631.

1995b. Intragenic recombination of a single plant pathogen gene provides a mechanism for the evolution of new host specificities. I. Bacteriol. 177: 4963-4968.

Yang, Y., R. De Feyter, and D.W. Gabriel. 1994. Host specific symptoms and increased release of Xanthomonas citri and $X$. campestris pv. malvacearum from leaves are determined by the $102 \mathrm{bp}$ tandem repeats of $p t h A$ and $a v r b 6$, respectively. Mol. Plant-Microbe Interact. 7: 345-355.

Yang, Y., Q. Yuan, and D.W. Gabriel. 1996. Watersoaking functions(s) of XcmH1005 are redundantly encoded by members of the Xanthomonas avr/pth gene family. Mol. Plant-Microbe Interact. 9: 105-113.

Ye, X.S., S.A. Avdiushko, and J. Kuc. 1995. Protein phosphorylation in tobacco plants with systemic resistance induced by tobacco mosaic virus. Physiol. Mol. Plant Pathol. 47: 269283.

Yu, L.M., C.J. Lamb, and R.A. Dixon. 1993. Purification and biochemical characterization of proteins which bind to the H-box cis-element implicated in transcriptional activation of plant defense genes. Plant I. 3: 805-816.

Yu, Y.G., G.R. Buss, and M.A.S. Maroof. 1996. Isolation of a superfamily of candidate disease resistance genes in soybean based on a conserved nucleotide-binding site. Proc. Natl. Acad. Sci. 93: 11751-11756.

Zhang, B. and K.B. Singh. 1994. ocs element promoter sequences are activated by auxin and salicylic acid in Arabidopsis. Proc. Natl. Acad. Sci. 91: 2507-2511.

Zhang, B., R.C. Foley, and K.B. Singh. 1993. Isolation and characterization of two related Arabidopsis ocs-element bZIP binding proteins. Plant I. 4: 711-716.

Zhang, B., W. Chen, R.C. Foley, M. Büttner, and K.B. Singh. 1995a. Interactions between distinct types of DNA-binding proteins enhance binding to ocs element promoter sequences. Plant Cell 7: 2241-2252.

Zhang, S. and D.F. Klessig. 1997. Salicylic acid activates a 48 kDa MAP kinase in tobacco. Plant Cell 9: 809-824.

Zhang, Z., D.B. Collinge, and H. Thordal-Christensen. 1995b. Germin-like oxalate oxidase, a $\mathrm{H}_{2} \mathrm{O}_{2}$-producing enzyme, accumulates in barley attacked by the powdery mildew fungus. Plant I. 8: 139-145.

Zhou, J., Y.-T. Loh, R.A. Bressan, and G.B. Martin. 1995. The tomato gene $p t i$ encodes a serine/threonine kinase that is phosphorylated by Pto and is involved in the hypersensitive response. Cell 83: 925-935.

Zhou, J., X. Tang, and G.B. Martin. 1997. The Pto kinase conferring resistance to tomato bacterial speck disease interacts with proteins that bind a cis-element of pathogenesis-related genes. EMBO /. 16: 3207-3218.

Zhu, Q., W. Dröge-Laser, R.A. Dixon, and C. Lamb. 1996. Transcriptional activation of plant defense genes. Curr. Opin. Genet. Dev. 6: 624-630. 


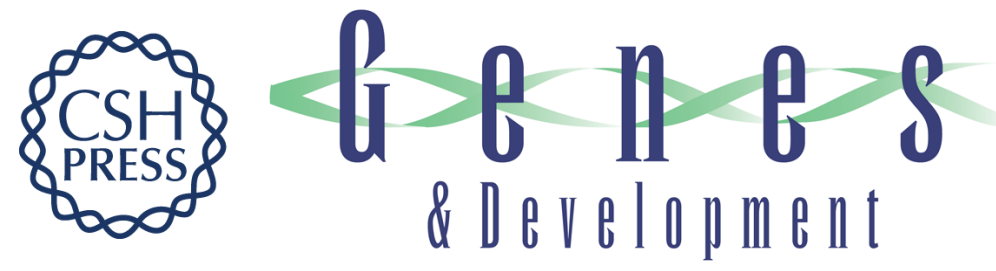

\section{Signal perception and transduction in plant defense responses.}

Y Yang, J Shah and D F Klessig

Genes Dev. 1997, 11:

Access the most recent version at doi:10.1101/gad.11.13.1621 $\begin{array}{ll}\text { References } & \begin{array}{l}\text { This article cites } 234 \text { articles, } 127 \text { of which can be accessed free at: } \\ \text { http://genesdev.cshlp.org/content/11/13/1621.full.html\#ref-list-1 }\end{array}\end{array}$

License

Email Alerting Receive free email alerts when new articles cite this article - sign up in the box at the top Service right corner of the article or click here.

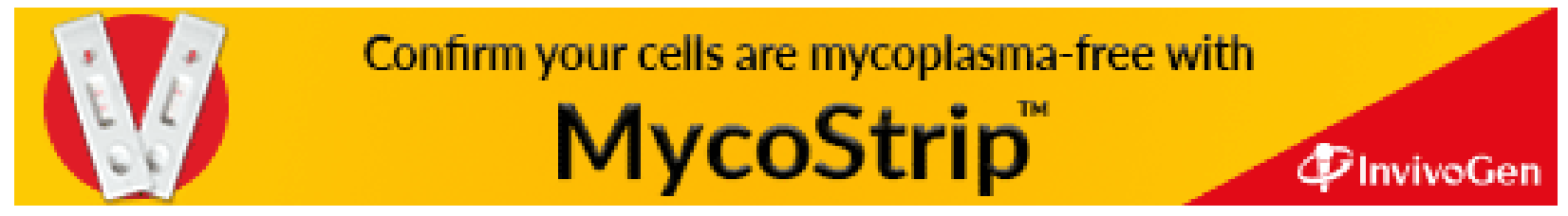

